\begin{tabular}{ccc} 
Coğrafi Bilimler Dergisi & Coğrafi \\
Bilimler & Dergisi \\
\hline & Turkish Journal of Geographical Sciences & e-ISSN:1308-9765 \\
\hline
\end{tabular}

\title{
Antropojenik Jeomorfoloji Kapsamında Rölyefin Değişim Analizi: Ataşehir (İstanbul) Örneği
}

\author{
Analysis of relief change in the scope of anthropogenic geomorphology: The \\ case of Ataşehir (Istanbul)
}

Murat Uzun*a

\begin{tabular}{|c|c|}
\hline Makale Bilgisi & $\ddot{O} z$ \\
\hline $\begin{array}{l}\text { DOI: } \\
10.33688 / \text { aucbd.684790 }\end{array}$ & $\begin{array}{l}\text { Jeomorfolojik unsurlar çeşitli dinamik süreçlerle şekillenmekteyken, } \\
\text { insanoğlunun bu sürece dâhil olması farklı boyutlarda değişimlerin meydana }\end{array}$ \\
\hline $\begin{array}{ll}\text { Makale Geçmişi: } \\
\text { Geliş: } & 04.02 .2020 \\
\text { Kabul: } & 13.04 .2020 \\
\end{array}$ & $\begin{array}{l}\text { gelmesine neden olmuş ve antropojenik jeomorfoloji kavramının ortaya çıkmasını } \\
\text { sağlamıştır. Bu çalışmada da farklı etkenlerle antropojenik jeomorfoloji } \\
\text { unsurlarının gözlemlenebildiği Istanbul-Ataşehir ilçesi örneğinde, eski -yeni }\end{array}$ \\
\hline $\begin{array}{l}\text { Anahtar Kelimeler: } \\
\text { Antropojenik Jeomorfoloji } \\
\text { Rölyef Değişimi } \\
\text { Coğrafi Bilgi Sistemleri } \\
\text { (CBS) } \\
\text { Ataşehir-İstanbul }\end{array}$ & $\begin{array}{l}\text { topografik verilerin Coğrafi Bilgi Sistemleri (CBS) ile karşılaştırması sonucu } \\
\text { ortaya çıkan farklı rölyef değişim analizleri ve bu değişimde rol oynayan } \\
\text { antropojenik birimlerle neden-sonuç ilişkisi incelenmiştir. Araştırmada rölyef } \\
\text { değişimi ve antropojenik etki faktörlerinin belirlenmesi için birçok aşamadan } \\
\text { oluşan sistematik uygulanmıştır. Uydu görüntüleri ile Ataşehir'de arazi kullanım } \\
\text { durumu ve değişen koşullar tespit edilmiş, rölyef değişimi ise geçmiş ve günümüze } \\
\text { ait sayısal yükselti modeli üzerinden üç farklı aşamada analiz edilerek } \\
\text { karşılaştırılmıştır. Çalışmanın sonunda ise belirlenen birçok rölyef değişim } \\
\text { analizi, antropojenik faktör birimleri ve alt parametreleriyle korelasyon analizine } \\
\text { tabi tutulmuş ve aralarındaki ilişki açıklanmıştır. Araştırma sonucunda, } \\
\text { gözlemlenebilir olarak ilçenin \% } 29 \text { 'unda rölyef değişimi tespit edilirken farklı } \\
\text { analizlere göre mikro ve makro ölçekte arazinin birçok noktasında topografik } \\
\text { yüzey yeniden tanzim edilerek değiştirilmiştir. }\end{array}$ \\
\hline
\end{tabular}

\section{Article Info}

DOI:

$10.33688 /$ aucbd .684790

Article History:

Received: 04.02.2020

Accepted: 13.04.2020

Keywords:

Anthropogenic Geomorphology

Relief Change

Geographic Information

Systems (GIS)

Ataşehir-Istanbul

\begin{abstract}
While the geomorphological elements are shaped by various dynamic processes, the involvement of human beings in this process has led to changes in different dimensions and led to the emergence of the concept of anthropogenic geomorphology. In this study, anthropogenic geomorphology elements can be observed with different factors in Istanbul-Atasehir district, the old and new topographic data compared with the Geographical Information Systems (GIS) and different anthropogenic units that play a role in this change is investigated. In this study, a systematic method consisting of several stages was used to determine relief change and anthropogenic effect factors. Land use status and changing conditions in Ataşehir were determined by satellite images, and relief changes were analyzed and compared in three different stages over the digital elevation model of the past and present. At the end of the study, most of the relief change analyzes determined were subjected to correlation analysis with anthropogenic factor units and sub-parameters and the relationship between them was explained. As a result of the research, 29\% of the districts were observed to have relief changes, and according to different analyzes, the topographic surface was re-arranged at many points of the land at micro and macro scale.
\end{abstract}

\footnotetext{
*Sorumlu Yazar/Corresponding Author: Murat Uzun, murat_uzun53@hotmail.com

a Marmara Üniversitesi, Sosyal Bilimler Esntitüsü, Coğrafya Anabilim Dalı, İstanbul/Türkiye https://orcid.org/0000-00032191-3936
} 


\section{Giriș}

Uzun bir serüveni olan Dünya'nın ve buradaki doğal unsuların yapısı, özellikleri ve dinamik işleyiş süreçleri, insanoğlunun bu serüvene dâhil olmasıyla birlikte hızlı bir şekilde değişmeye ve farklı özellikler göstermeye başlamıştır. Özellikle jeomorfolojik, klimatolojik ve hidrografik unsurlarla insan faaliyetleri arasında geçmişten günümüze farklı boyutlarda etkileşimler meydana gelmektedir (Brandolini vd., 2019: 3; Ekinci 2006: 124; Golomb ve Eder, 1964: 4; Goudie, 1993: 40; Tarolli 2016: 2301). Günümüz koşullarında bu etkileşimin boyutları değişmekte ve değişimin temel nedenlerinin başında ise artan beşeri baskıların varlığı yer almaktadır (Castree, 2014: 439; Li vd., 2017: 110; Szabó vd., 2010: 5; Tarolli ve Sofia, 2016: 140). Meydana gelen etkileşimler ise insan etkisi olarak açıklanabilen antroposen kavramının bilim camiasında tartışılmasını sağlamış ve doğal olarak kendine yer edinmesinde etkili olmuştur (Brown, 1970: 76; Crutzen ve Stoermer, 2000:17; Efe vd., 2008: 318; Ellis, 2017: 526; Jefferson 2013: 2; Steffen vd., 2011: 843; Syvitski 2012: 13; Zalasiewicz vd., 2008: 5; Zalasiewicz vd., 2015: 198). Etki alanını genişleten insanoğlunun jeomorfolojik oluşum-gelişim süreçlerini değiştirmesi ve bu süreçlerde önemli bir aktör haline gelmesi doğal olarak antropojenik jeomorfoloji (antropojeomorfoloji) kavramının gelişmesine de ön ayak olmuştur (Harden vd., 2014: 5; Li vd., 2017: 110; Szabó vd., 2010: 13). Yakın zamanda ortaya çıkan ve çok çeşitli sistematikler kapsamında değerlendirilen, aynı zamanda tartışılan antropojenik jeomorfoloji; insan faaliyetlerinin doğrudan yada dolaylı olarak morfojenetik süreçlere müdahale etmesi, farklı boyutlarda yapay yer şekillerini ortaya çıkarması yada var olan topografik görünümde değişikliklere yol açması olarak tanımlanmaktadır (Brown vd., 2017: 75; Ertek, 2015: 346; Ertek, 2017: 73; Harden, 2013: 77; Karataş 2016: 444; Knitter vd., 2019: 3; Nir, 1983: 88; Özşahin, 2013b: 926; Szabó vd. 2010: 6). Antropojeomorfoloji aynı zamanda insanın meydana getirdiği değişimleri, farklı boyutlarını, morfolojik birimlerin oluşturacağı muhtemel riskleri ve geleceğe dönük etkilerini de incelemektedir (Ertek 2016: 202; Li vd., 2017: 111; Özşahin 2013b: 927). Bu nedenle temel bir sistematik ve yöntem anlayış1 tartışmaları olsa da geçmişten günümüze birçok bilimsel çalışmanın 1şığında temel aldığı bazı işleyiş yöntemlerine sahiptir (Brown vd., 2017: 75; Ertek, 2017: 78; Harden, 2013: 77; Karataş, 2016: 444; Knitter vd., 2019: 3; Li vd., 2017: 113; Nir 1983: 89; Rózsa, 2007: 234; Rózsa ve Novak 2011: 110; Szabó vd. 2010: 6; Tarolli, 2016: 2301; Ursu vd., 2011: 93; Uzun, 2020: 320; Verburg vd., 2016: 334; Walker, 1991: 3). Günümüz koşullarında insanın her türlü topografik görünümde ve dinamik süreçlerde etkili olması antropojenik jeomorfolojinin artık jeomorfoloji disiplinin bir alt dalı olarak kabul görmesini de sağlamıştır (Szabó 2010: 3).

Geçmişte insanoğlunun oldukça küçük etkilerle değişme uğrattı̆̆ rölyef, görünüm açısından mikro ölçekli topografik birimlerle açıklanabilmekteyken sanayi devrimi ve günümüzün gelişen teknolojik ilerlemelerine bağlı olarak oldukça devasa yapay yer şekillerinin gözlemlenmesine ve rölyef üzerinde büyük boyutlarda değişimlerin yaşanmasına neden olmaktadır (Goudie ve Viles 2016: 17; Jefferson vd., 2013: 1; Karataş, 2016: 444; Szabó vd., 2010: 13). Bu bakımdan antropojenik jeomorfolojide şehirsel gelişim, sanayi, ulaşım, maden-enerji sahaları, kıyı dolgu alanları ve limanlar, turizm odaklı yapılar ve birçok çeşitli unsurla rölyef üzerinde yoğun değişimlere sahne olurken yapay morfolojik birimleri de ortaya çıkarmaktadır (Ekinci, 2006: 126; Ekinci ve Yalçınkaya 2015: 347; Erkal ve Taş 2013: 209; Güner, 2019: 42; Kopar vd., 2018: 38; Manea vd., 2011: 37; Szabó vd., 2010: 13). 
Meydana gelen değişimler ise genel olarak aşındırma-kazma ve biriktirme-doldurma gibi iki temel morfojenetik süreçle oluşmaktadır. Bu iki sürecin boyutlarının değişkenlik göstermesi farklı yapay görünümlerin ortaya çıkmasını sağlarken daha küçük boyutlarda meydana gelen tesviye-düzleştirme işlemi ise antropojenik sürece üçüncü bir boyut katmaktadır (Ertek 2017: 78; Karataş 2016: 444; Szabó vd., 2010: 13; Uzun, 2020: 322) Tek bir süreç yada karmaşık süreçlerin görülebildiği antropojenik jeomorfoloji sahalarındaki bilimsel çalışmalar ise günümüzün gelişen teknolojik imkanlarıyla oldukça detaylı şekilde tespit edilebilmekte, dağılışı ve etkileri farklı sistematiklerle analiz edilebilmektedir (Brandolini vd., 2019: 2; Tarolli ve Sofia, 2016: 142; Xiang vd., 2019: 2).

Sanayi ve diğer gelişmelere bağlı olarak Dünya nüfusunun artmasıyla birlikte kırdan kente yoğun bir göç yaşanmış ve şehirsel alanlar oldukça genişlemiştir. Gelişen ve genişleyen kentsel alanlarda, yerleşim, sanayi ve ulaşım odaklı topografik değişimler meydana gelmektedir. Ülkemiz koşullarında da yoğunlaşan bu olgu günümüz şartlarında nüfus ve kentsel yayılım alanları oldukça büyük şehirlerin ortaya çıkmasını sağlamıştır. Bu alanların başında Türkiye'nin en fazla nüfusa sahip ili İstanbul gelmektedir. İstanbul, coğrafi konumu ile jeomorfolojik, klimatolojik ve hidrografik koşullarının sağladığı olanaklar sayesinde geçmişten günümüze daima beşeri faaliyetlerin merkezi olmuş ve kentsel alanı oldukça geniş sahalara yayılmıştır (Döker, 2012: 174). Bu alanlardan birini oluşturan Ataşehir, 6 Mart 2008'de 5747 Sayılı Büyükşehir Belediyesi kanununda yapılan değişiklikle 17 mahallenin oluşturduğu ilçe statüsünde idari yönetsel alana dönüşmüş ve günümüzde yoğun nüfuslu bir sahayı oluşturmuştur (Döker, 2012: 60). Ataşehir'de yaşanan kentsel gelişim ile değişen arazi kullanımı sonucu yerleşim alanlarının farklı boyutlardaki değişim etkisi, ana ulaşım yolları bağlantılarının bulunması, yüksek katlı bina yapılarının çoğalması, ilçenin tamamen yerleşim sahasına dönüşmesi, değişen rölyef koşullarının muhtemel riskler ihtiva etmesi araştırmada bu alanının seçilmesinin temel nedenleridir. İnceleme alanında 1980'li yıllardan sonra yaşanan göç ile yerleşim alanlarının genişlemesi, ana ulaşım yolları ile bağlantılarının yapımı, son yıllardaki yüksek katlı binaların varlığı, topografik görünümünün de değişmesine yol açmış, rölyef yeniden tanzim edilmiştir. Bu kapsamda çalışmanın amacını; Ataşehir ilçesinde, eski ve yeni topografik verilerin Coğrafi Bilgi Sistemleri (CBS) üzerinden farklı sistematiklerle karşılaştırılması, analiz edilmesi, değişen rölyefin farklı boyutları ile dağılışının saptanması, değişimde rol oynayan antropojenik etkenlerin belirlenmesi ve bütün verilerin analizlerinin yapılarak neden-sonuç ilişkisinin ortaya konması oluşturmaktadır. Belirtilen amaçlar doğrultusunda çalışmanın varsayımı, gelişen şehirsel alanlarda farklı antropojenik etkenlerin topografik görünümde küçük ve büyük boyutlarda rölyef değişimine neden olduğudur.

\section{2. Çalışma Alanı}

İnceleme alanı, İstanbul iline bağlı Ataşehir İlçe sınırlarından oluşmaktadır. Bu bakımdan araştırma sahası İstanbul Anadolu yakasında ve Kocaeli Platosu üzerinde yer alır. Temel olarak ilçe sınırlarını fiziki ve beşeri unsurlar birlikte oluşturmaktadır. İlçe sınırlarının doğusunu Kayışdağ yamaçları ile Çamaşırlık (Fındıklı) Deresi meydana getirirken, güneyini D-100 karayolu, kuzeyini TEM (O-4) otoyolu, batısını ise Libadiye caddesi oluşturmaktadır. İlçenin kuzeyinde Ümraniye, kuzeydoğusunda Sancaktepe, batı-kuzeybatısında Üsküdar, güneybatısında Kadıköy, güneygüneydoğusunda Maltepe ilçeleri bulunmaktadır (Şekil 1). İnceleme alanını oluşturan Ataşehir ilçesi 
idari sınırları $29^{0} 4^{\prime}-29^{0} 12^{\prime}$ Doğu boylamları ile $40^{0} 57^{\prime}-41^{0} 1^{\prime}$ Kuzey enlemleri arasında yer alır ve toplam 24,98 km²'lik alan kaplamaktadır. Ataşehir ilçesi toplam 17 mahalleden oluşmaktadır (Şekil 1).
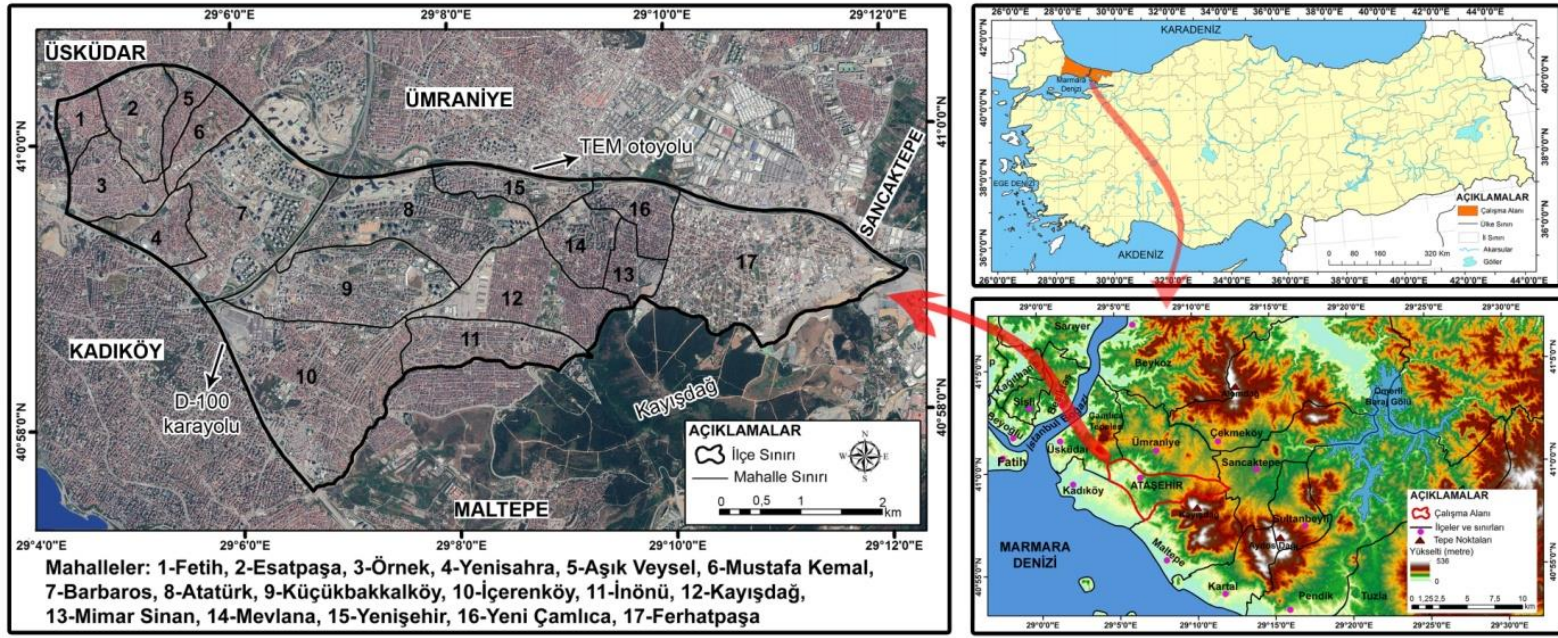

Şekil 1. Çalışma Alanının Lokasyon haritası

Çalışma sahasında jeolojik açıdan en yaşlı birimlerini Paleozoyik yaşlı Kurtköy, Aydos, Yayalar, Pelitli ve Kartal formasyonları meydana getirmektedir (Şekil 2). Kurtköy formasyonu ilçenin doğusunda, Kayışdağ'ın kuzeydoğu eteklerinde kumtaşı, çakıltaşı ve çamurtaşı birimlerinden oluşmaktadır (Özşahin, 2013a: 83). Aydos, Yayalar ve Pelitli formasyonları dar alanlı olarak TEM otoyolu kenarında gözlemlenmektedir. Orta Devoniyen yaşlı Kartal formasyonu ise kireçtaşı, şeyl, grovak birimlerinden müteşekkil olup Kurbağalıdere'nin doğu ve batısında D-100 karayoluna doğru yayılış göstermektedir. Miyosen yaşlı Meşetepe formasyonu ilçenin kuzeydoğusunda Kayışdağ'ın yamaçlarında, Kocaeli Platosu aşınım yüzeylerine doğru gözlemlenmektedir (Ertek, 2010: 27; Özşahin ve Ekinci, 2013: 16). Kuvaterner yaşlı eski alüvyonlar Kayışdağ eteklerinden güneybatı yönlü olarak Kurbağalıdere yatağına kadar uzanmaktadır. Kurbağalıdere yatağında ise alüvyonlar yer almaktadır. Sahanın jeolojik gelişimi yapısal hareketlerden, tektonik etkenlerden ve en son flüvyal süreçlerden meydana gelen farklı dinamik süreçlerin ortak etkisiyle oluşmuştur (Ak, 2010: 23; Ertek, 2008: 268; Özşahin, 2013a: 83; Şengör ve Özgül, 2010).
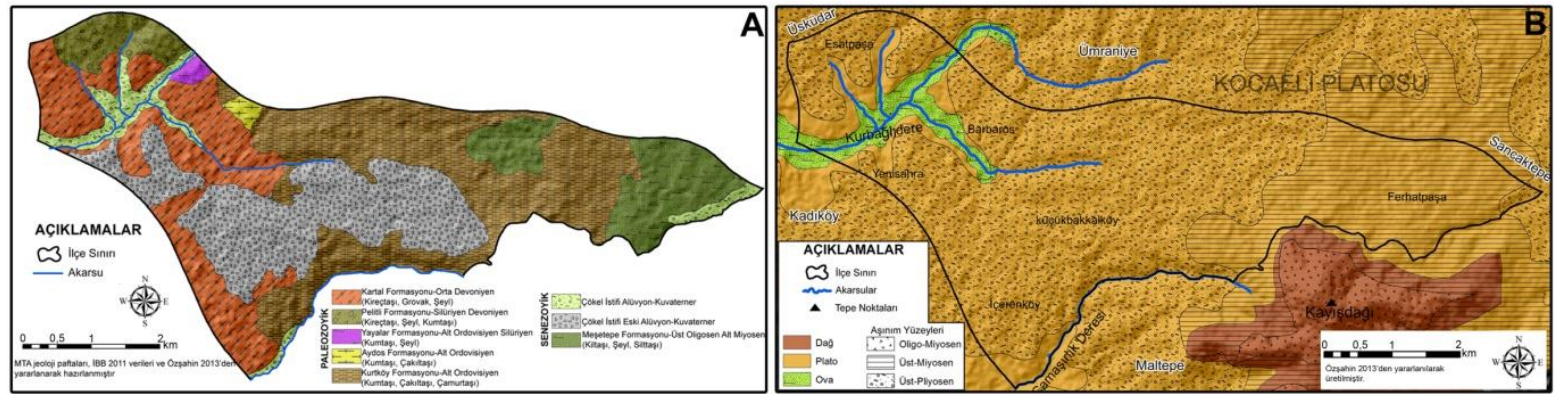

Şekil 2. A) Ataşehir Jeoloji Haritası, B) Ataşehir ve Çevresinin Jeomorfoloji Haritası

İnceleme alanının en alçak seviyesi Kurbağalıdere tabanında 10-15 m. iken en yüksek seviye Kayışdağ yamaçlarında 225 m.de yer almaktadır. Ortalama yükselti değeri 105,24 m.dir. Yükselti amplitüdü 110 m.dir. Yükselti genel olarak kuzeybatıdan güneydoğuya doğru artmaktadır. Bu noktada 
Kayışdağ en önemli yükseltiyi meydana getirmektedir. Eğim değerleri açısından inceleme alanı değerlendirildiğinde, ortalama eğim değeri 5,23 derecedir. Düz ve düze yakın alanların $\left(0^{0}-5^{0}\right)$ sahanın yarısından fazlasını oluşturduğu gözlemlenmektedir. En yüksek eğim değerinin $20^{\circ}$ 'nin üstünde olup ve bu alanlar İnönü mahallesinde Çamaşırlık Deresi vadisi ile Kayışdağ yamaçlarında, Barbaros, Yenisahra, Örnek ve M. Kemal mahallelerinde Kurbağalıdere vadisinde gözlemlenmektedir (Şekil 3). Sahanın plato özelliği ve flüvyal aşınım nedeniyle bakı yönlerinin birbirine çok yakın alanlar kapladığı ve bu şekilde hakim bir yamaç yönü eğiliminin olmadığı anlaşılmaktadır (Şekil 3).
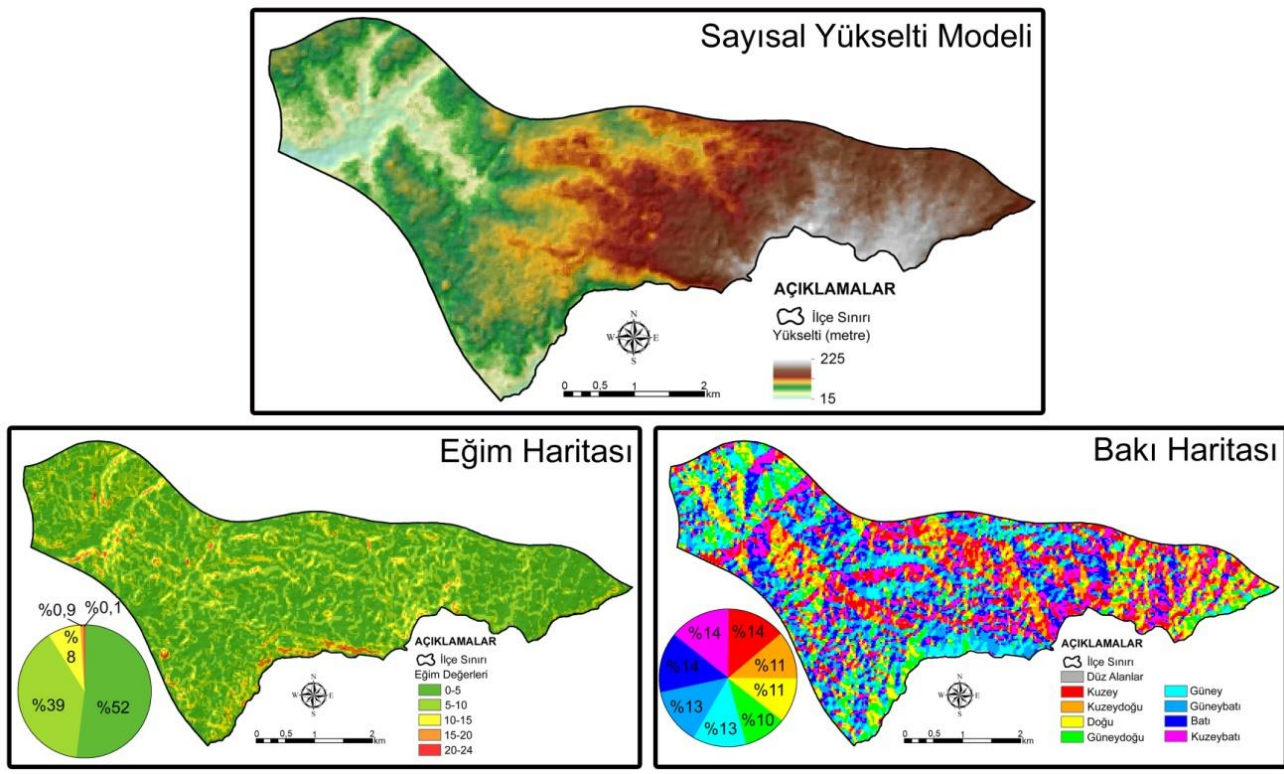

Şekil 3. Ataşehir İlçesinin Sayısal Yükselti Modeli (SYM-DEM), Eğim Haritası ve Bakı Haritası

Çalışma alanı ve yakın çevresinin temel jeomorfolojik birimlerini Kayışdağ, Kocaeli Platosu ve Kurbağalıdere'nin yatağında yer alan ova sahası oluşturmaktadır. Anadolu yakasının yer aldığı Kocaeli Platosu üzerinde bulunan inceleme sahası bu alandaki 100-200 m arasında alçak plato özelliği göstermektedir (Ertek, 2008: 268; Ertek, 2010). İnceleme alanı sınırları içerisinde dağlık-tepelik alanlar yer almasa da güneydoğu sınırını teşkil eden Kayışdağ $(438 \mathrm{~m})$ en önemli yüksek kütleyi meydana getirmektedir. Ova ve alüvyal düzlükler Kurbağalıdere'nin yatağında oldukça dar şekilde gözlemlenmektedir (Şekil 2). Bu alanda ova düzlükleri ile alçak plato sahasına geçiş önemli irtifa farklarının oluşmasını sağlarken eğim değerlerinin de artmasına neden olmuştur. Plato alanları jeomorfolojik gelişim dönemlerindeki tektonik hareketler ve iklim salınımlarının etkisiyle farklı evlerden geçmiş ve günümüzde bu sahalar çeşitli kademelerde aşınım yüzeylerini meydana getirmiştir. İlçenin güneydoğusunda $300 \mathrm{~m}$. seviyesindeki Oligo-Miyosen aşınım yüzeyi Kayışdağ eteklerinde gözlemlenmekte iken, ilçe sınırları içerisinde 200-300 m. seviyesinde Üst-Miyosen ve 50-200 m. seviyesinde Üst-Pliyosen aşnım yüzeyleri gözlemlenmektedir (Özşahin ve Ekinci, 2013: 20; Şengör ve Özgül, 2010). İnceleme alanında neojen depolarında gelişen Üst-Pliyosen aşnım yüzeyleri etkin olan flüvyal süreçlerle parçalanmış ve günümüzde deforme olmuştur. Günümüz koşullarında ise inceleme alanının tamamı beşeri faaliyetlerin etkisi altında olup jeomorfolojik görünüm tamamen antropojenik etkenlerin değişim boyutlarıyla karşı karşıya kalmıştır. İnceleme alanı yoğun antropojenik etkilere 
maruz kaldığı için günümüzde yüzeysel akışlar doğal dinamik yapısının dışına çıkmıştır. Sahada yer alan Kurbağalıdere ve Çamaşırlık Deresi en önemli hidrografik unsurları oluşturmaktadır.

İlçenin 2019 yılı Adrese Dayalı Nüfus Kayıt Sistemine (ADNKS) göre toplam nüfus 425.094 kişidir. Ataşehir geçmiş dönemlerde idari olarak farklı kesimleri ile birçok ilçenin sınırları içerisinde yer almıştır. Ancak Ataşehir, 2008 yılında yapılan kanun değişikliği ile ilçe statüsünü almış ve günümüzde 17 mahalleden oluşmaktadır. İlçe sınırlarının tamamı yerleşim alanı olup büyük bir sanayi alanı bulunmamaktadır. Çalışma alanı daha çok iş ve ticaret merkezleri ile yoğun bir ulaşım ağının orta noktasında bulunmaktadır. Sahanın kuzeyinde TEM otoyolu ve bağlantı yolları ile güneyde D-100 karayolu, İstanbul Anadolu yakasının en önemli ulaşım ağlarını oluştururken inceleme alanının da sınırlarını meydana getirmektedir.

\section{Materyal ve Yöntem}

Araştırmanın temel materyallerini, Harita Genel Müdürlüğü’nden temin edilen 1980 yılına ait 1:25.000 ölçekli F22d3, F22d4, G22a1 ve G22a2 topografya haritası paftaları, Meti\&Nasa yapımı olan 30 m çözünürlüklü AsterGDEM verisi, MTA'dan temin edilen 1:100.000 ölçekli jeoloji paftaları, Türkiye İstatistik Kurumu (TÜİK)'dan alınan nüfus verileri, Landsat ve Google Earth Pro uydu görüntüleri, İstanbul Büyükşehir Belediyesi'den (İBB) altlık haritaları, uydu görüntüsü ve hava fotoğrafi, Ataşehir Belediyesi altlık harita verileri ve saha ile ilgili önceki çalışmalar oluşturmaktadır. Diğer temel veriler ise, arazi çalışmalarıyla elde edilen saha fotoğrafları ve arazi ölçümlerden oluşmaktadır. Temin edilen bütün verilerle coğrafya araştırma yöntem ve teknikleri kapsamında ilk olarak çalışma planı oluşturulmuş, daha sonra Coğrafi Bilgi Sistemleri (CBS) ile haritalar üretilmiş, analiz ve sorgulamalar yapılmıştır. Araştırmanın ilk safhasında konu ve saha ile ilgili literatür taraması sonucu elde edilen kaynaklar incelenmiş, kavramsal çerçeve detaylandırılmış ve inceleme alanının coğrafi özellikleri açıklanmıştır. Daha sonra temin edilen altlık haritalar ArcGIS 10.3 yazılımına aktarılmış, sayısallaştırma ve dönüşüm işlemleri yapılmıştır (Şekil 4). İlk olarak topografya paftaları ve AsterGDEM verileri üzerinden inceleme alanının eski ve yeni Sayısal Yükselti Modeli (SYM)-DEM verileri oluşturulmuştur. Bütün veriler UTM projeksiyonuna, WGS 84 datumuna dönüştürülmüş ve birbirlerine örtüşmesi sağlanmıştır. İki veride de eşyükselti eğrisi aralığı (eküdistans) $10 \mathrm{~m}$ olarak ayarlanmış ve bu verilerden sayısal yükselti modeli (SYM yada DEM) üretilerek raster veri formatına dönüştürülmüştür. Daha sonra incelenen kaynaklar, arazi çalışmaları, DEM verisi ve altlık haritalar üzerinden çalışma sahasının yükselti, eğim, bakı, yüzey büküklüğü, jeoloji ve jeomorfoloji haritaları üretilmiştir.

Çalışma sahasında antropojenik jeomorfoloji koşulları ve rölyef değişimini tespiti için birden çok aşamalı sistematik uygulanmış ve bütün veriler ilişkisel olarak analiz edilerek karşılaştırılmıştır (Şekil 4). Bu kapsamda ilk olarak İBB'den 1970 ve 1982 yıllarına ait hava fotoğrafları, United States Geological Survey (USGS)'den 1975 ve 1980 tarihli Landsat MSS, 01.09.1990 tarihli Landsat TM, 15.05.2000, 26.07.2010 tarihli Landsat ETM ve 08.07.2019 tarihli Landsat OLI verileri, Google Earth Pro'dan 2007, 2009, 2010, 2019 ve 2020 yıllarına ait yüksek çözünürlüklü (4800x2966 ve 300 DPI) uydu görüntüleri alınmıştır. Hava fotoğrafları ArcGIS 10.3 yazılımında sayısallaştırma ile uydu görüntüleri ise bant kompozisyonları düzenlenerek kontrollü sınıflandırma yöntemi uygulanmış ve arazi 
kullanımının yıllar içerisindeki değişimi tespit edilmiştir. Elde edilen sonuçlar ile inceleme alanının şehirsel gelişimi, antropojenik etkenli rölyef değişim alanlarının yoğun olacağı yerler için ön bilgilere ulaşı1mıştır. Rölyef değişiminin tespiti için daha detaylı sonuçların elde edilmesinde kullanılabilecek LIDAR ve İHA teknolojilerine sahip olunmadığından dolayı DEM verileri ile arazi çalışmalarındaki ölçüm ve gözlemlerden faydalanılarak antropojenik değişim analizleri yapılmıştır. Ön bilgi çalışmalarından elde edilmesinden sonra rölyef değişiminin tespiti için ilk olarak aynı yükselti aralı̆̆ ve raster formata dönüştürülen eski (1980) ve yeni (2016) DEM verileri ArcGIS yazılımında raster calculator ile analiz edilmiştir. Yapılan analizler üç aşamalı olarak uygulanmıştır (Şekil 4). Bütün aşamalarda veriler raster formatına dönüştürülmüş ve raster calculator aracı ile eski-yeni veriler birbirine çakıştırılmış böylece değişen alanlar ortaya konmuştur. Birinci aşamada, topografik analizlerle (yükselti, eğim, bakı ana yönler, bakı tüm yönler, kurvatür, akış doğrultusu) altı farklı değişim analizi yapılmıştır. İkinci aşamada, aşınım parçalanma derecesi analizi kapsamında karelaj (grid) yönetimi uygulanmıştır. İlçe alanı dar alanlı olduğundan dolayı $1 \mathrm{~km}^{2}$ 'lik karelaj yerine daha detaylı veriler elde edtmek için 0,5x0,5 km'lik (0,25 km²'lik 127 grid) karelere ayrılmış, ayrılan her karede en alçak, en yüksek nokta ve irtifa farkı tespit edilmiş ve karelerin ortasına atanan nokta verisine sayısal değerleri eklenmiştir. Eski ve yeni DEM verisi için uygulanan bu yöntemle natural neighbor enterpolasyonu sonucu elde edilen veriler yine raster calculator aracı ile analiz edilmiş ve üç farklı değişim analizi daha üretilmiştir. Üçüncü aşamada, önceki aşamalardan elde edilen birçok değişim verisi bindirme (overlay) analizi ile birleştirilmiş ve beş farklı rölyef değişim analizi verisi üretilmiştir. Daha sonra ise bütün veriler değerlendirilmiş, eski ve yeni uydu görüntüleri ile arazi çalışmaları sonucu, rölyef değişim haritası arazi gözlem verilerine dayalı olarak üretilmiştir.

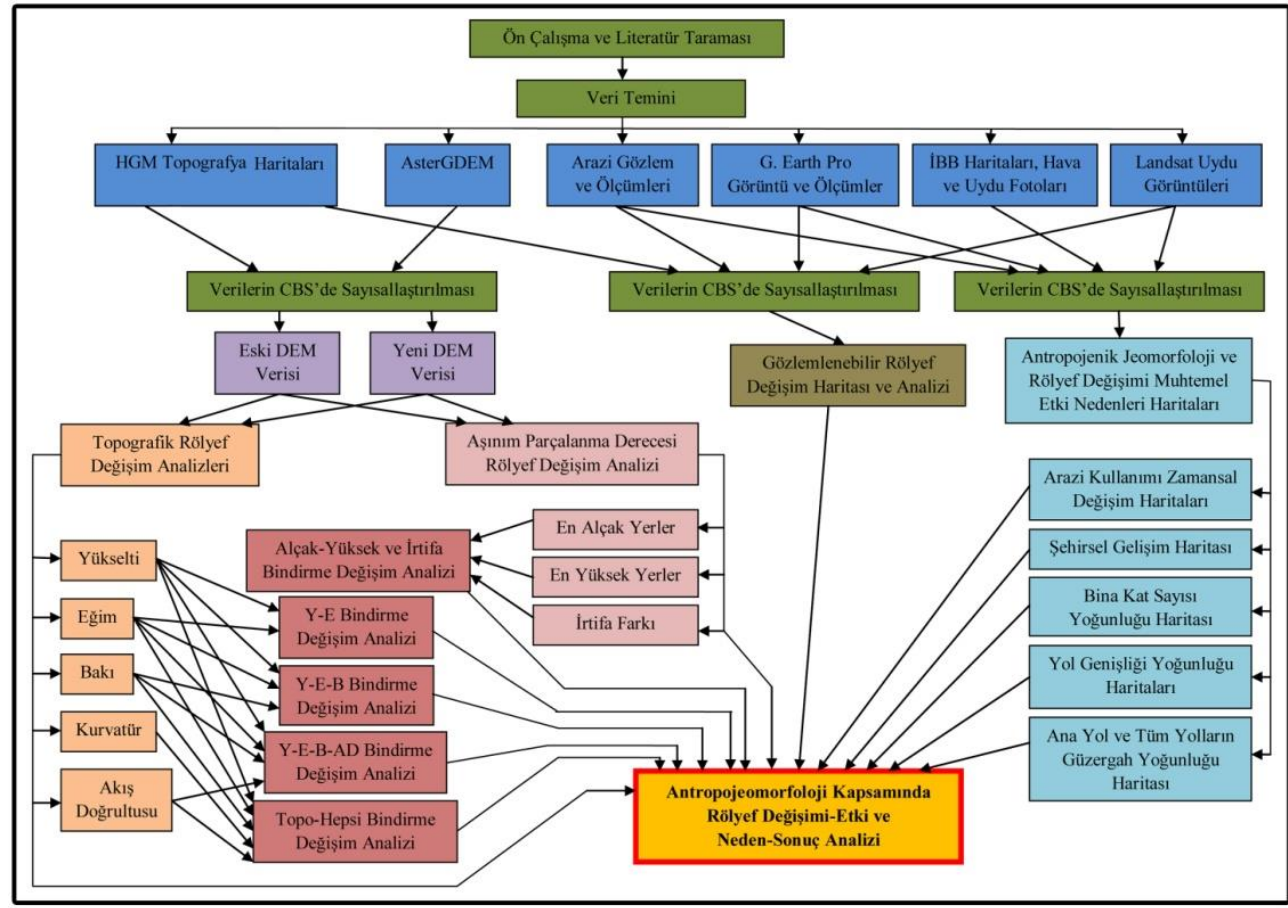

Şekil 4. Çalışmanın İş-Akış Şeması

Rölyef değişiminin hangi antropojenik etkenlerle oluştuğunu tespit etmek için muhtemel etki nedenlerinin haritaları oluşturulmuştur. Uydu görüntülerinden arazi kullanımı ve şehirsel gelişim 
haritaları oluşturulmuştur. Günümüz uydu görüntüsü ve arazi çalışmalarındaki gözlemlerle 1301 ölçüm nokta verisi ile bina kat sayısı yoğunluğu haritası ve 1048 ölçüm nokta verisinin (uydu görüntüsü üzerinden yapılan çizgisel ölçümler) natural neighbor enterpolasyonu ile yol genişliği yoğunluğu haritaları üretilmiştir (Şekil 5-B ve 5-C). Son olarak uydu görüntüsü üzerinden yapılan sayısallaştırma ile tüm yollar ve ana yolların (line density ile oluşturulan) yoğunluk analizi, iki farklı yoğunluk haritası kapsamında üretilmiştir.
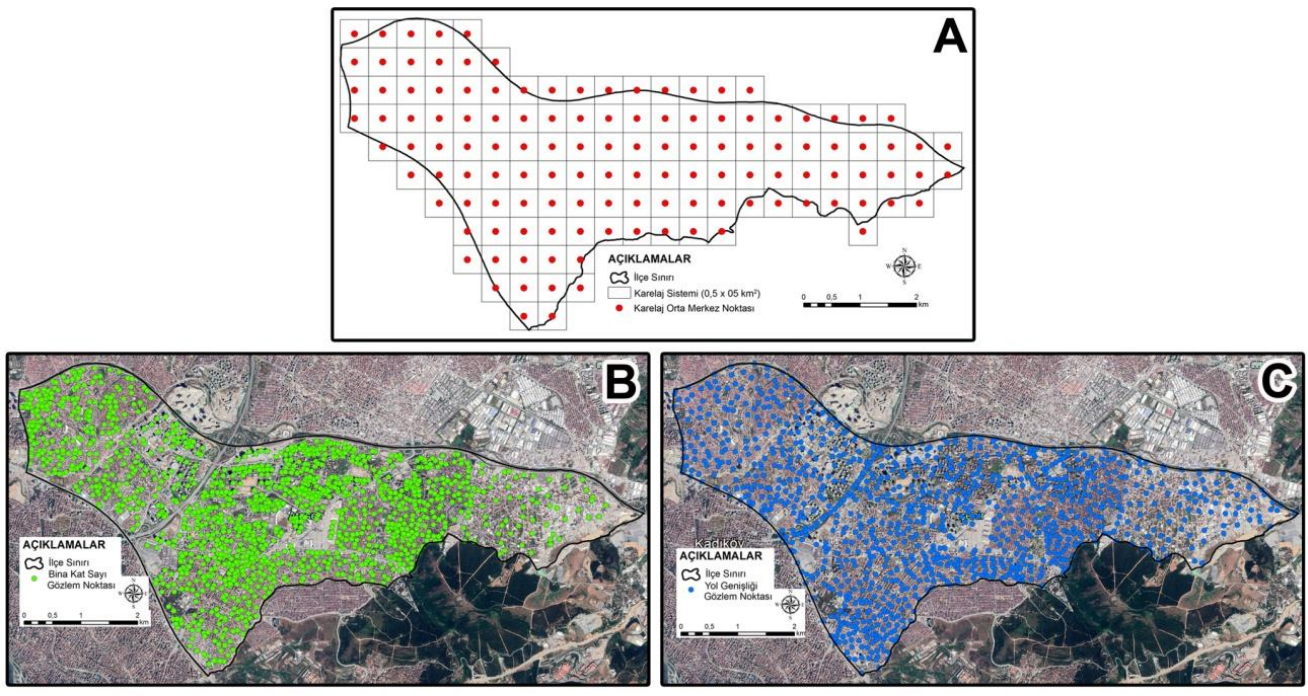

Şekil 5. A) Aşınım Parçalanma Derecesi Değişim Analizinde Kullanılan Karelaj Yöntemi ve Merkez Orta Noktaları, B) Bina Kat Sayısı Gözlem-Ölçüm Noktaları, C) Yol Genişliği Gözlem-Ölçüm Noktalar1

Çalışmanın sonunda ise rölyef değişim analizleri ile antropojenik etki faktörleri korelasyon analizlerine tabi tutulmuş ve değişimin etki nedenleri sayısal olarak anlamlı ilişkilerle açıklanmaya çalışılmıştır. Bu bakımdan değişimin inceleme alanının belli kesimlerinde yoğunlaştığı dokuz farklı rölyef değişim analiz verisi, altı farklı antropojenik etki faktörü ile tekrar analiz edilmiş, etki-sonuç ilişkisi üst ve alt parametreler kapsamında tespit edilmiş ve değerlendirilmiştir.

\section{Bulgular}

\subsection{Arazi Kullanımının Zamansal Değişimi ve Antropojenik Değişim Boyutu}

Çalışmadaki rölyef değişimin tespit edilmesi, boyutlarının ve nedenlerin sorgulanması için inceleme sahasının son 50 yıllık süreçteki arazi kullanım durumunun analizi yapılmıştır. Hava fotoğrafları ve uydu görüntülerinden elde edilen bulgularla sahanın arazi kullanımı açısından büyük değişimlere sahne olduğu anlaşılmaktadır. 1970 yılında, yerleşim alanı varlığı sadece \% 4 iken 2020 yılına gelindiğinde bu oran \% 66 olarak hesaplanmıştır (Şekil 6). Bu durumun oluşmasında İstanbul Anadolu yakasında meydana gelen kentsel gelişim süreci önemli rol oynamıştır. Türkiye genelinde özellikle 1985 yılından sonra yaşanan göç olgusuyla birlikte kent nüfusunun kır nüfusundan fazla olması, 1990 ve 2000'li yıllarda yoğun göç olgusunun devam etmesi, 2008 yılından itibaren inceleme alanının idari açısından ilçe statüsüne kavuşması ve çok katlı bina yapısı varlığı ile birlikte yerleşim alanı 50 yıllık süreçte 14 kat artış göstermiştir. 


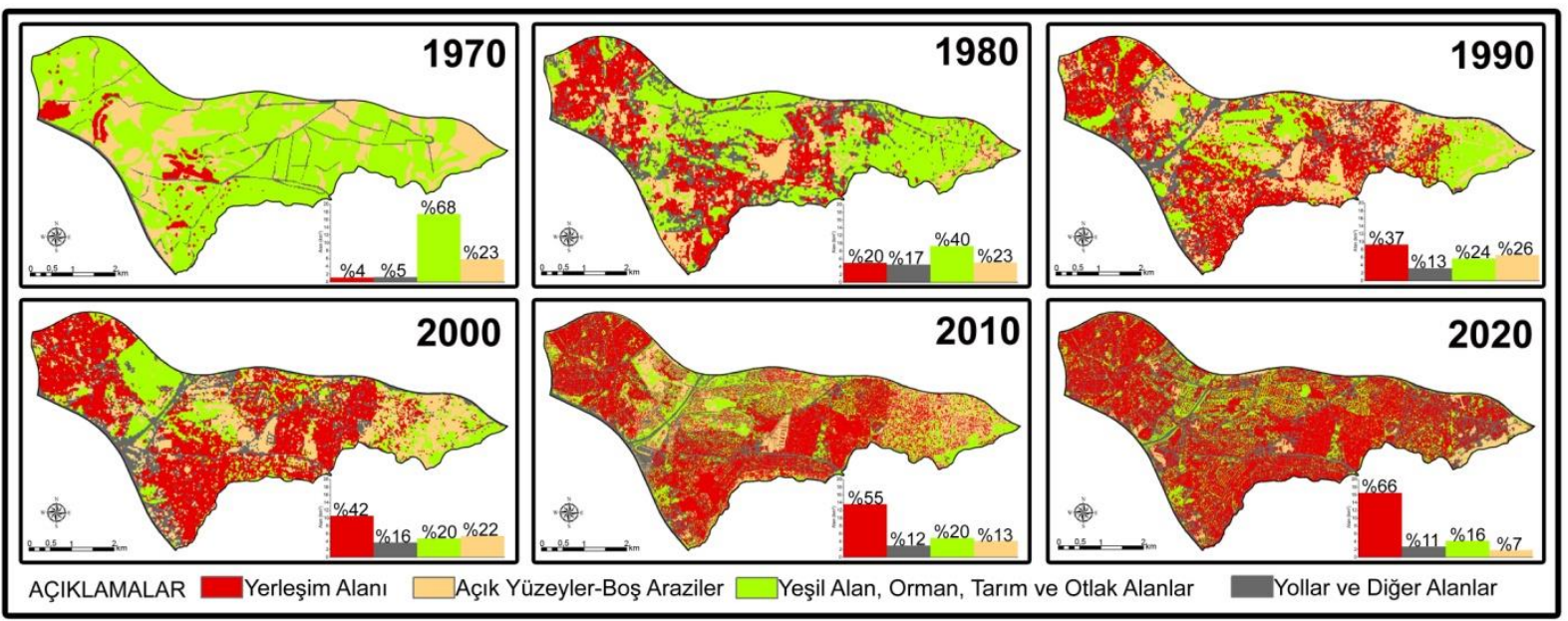

Şekil 6. Ataşehir'de Son 50 Yıllık Süreçteki Arazi Kullanımının Zamansal Değişimi

İnceleme alanında 1970 yılından günümüze yerleşim alanları daima artış eğiliminde iken yeşil alanlar kapsamındaki; tarım, orman, mera, otlak alan ve diğer yeşil alanlar daima azalma trendinde seyir izlemiştir. Yollar ve diğer alanlar 50 yıllık süreçte artma eğilimde iken açık yüzey ve boş araziler ise günümüze gelindiğinde arazi kullanımı açısından azalma eğilimindedir (Çizelge 1).

Çizelge 1. Ataşehir'de Arazi Kullanımının Yıllar İçerisindeki Alansal ve Oransal Değerleri

\begin{tabular}{|c|c|c|c|c|c|c|}
\hline \multirow[b]{2}{*}{ Arazi Kullanım Türleri } & \multicolumn{2}{|c|}{1970} & \multicolumn{2}{|c|}{1980} & \multicolumn{2}{|c|}{1990} \\
\hline & $\operatorname{Alan}\left(\mathrm{km}^{2}\right)$ & Yüzde(\%) & $\operatorname{Alan}\left(\mathrm{km}^{2}\right)$ & Yüzde(\%) & $\operatorname{Alan}\left(\mathrm{km}^{2}\right)$ & Yüzde(\%) \\
\hline Yerleşim alanı & 1,1176 & 4 & 5,1309 & 20 & 9,2372 & 37 \\
\hline Yollar ve diğer alanlar & 1,1979 & 5 & 4,2966 & 17 & 3,2557 & 13 \\
\hline Yeşil alan, orman, tarım vd., & 17,4820 & 68 & 9,8860 & 40 & 5,8449 & 24 \\
\hline \multirow[t]{2}{*}{ Açık yüzeyler, boş araziler } & 5,8334 & 23 & 5,6654 & 23 & 6,5170 & 26 \\
\hline & \multicolumn{2}{|c|}{2000} & \multicolumn{2}{|c|}{2010} & \multicolumn{2}{|c|}{2020} \\
\hline Arazi Kullanım Türleri & $\operatorname{Alan}\left(\mathrm{km}^{2}\right)$ & Yüzde(\%) & $\operatorname{Alan}\left(\mathrm{km}^{2}\right)$ & Yüzde(\%) & $\operatorname{Alan}\left(\mathrm{km}^{2}\right)$ & Yüzde(\%) \\
\hline Yerleşim alanı & 10,4218 & 42 & 13,6001 & 55 & 16,4455 & 66 \\
\hline Yollar ve diğer alanlar & 3,9761 & 16 & 3,0313 & 12 & 2,6447 & 11 \\
\hline Yeşil alan, orman, tarım vd., & 4,8649 & 20 & 5,021 & 20 & 4,0403 & 16 \\
\hline Açık yüzeyler, boş araziler & 5,5985 & 22 & 3,3262 & 13 & 1,8489 & 7 \\
\hline
\end{tabular}

1970 y1lında İçerenköy, Küçükbakkalköy, Yenisahra ve Örnek gibi günümüzün mahalleri o zamanın ise köy yerleşim alanlarından başlayan kentsel gelişim durumu, ilk olarak D-100 karayolu ve daha sonra TEM otoyolu ile bağlantı yolu ekseninde gelişmiş ve günümüzde ilçenin 2/3'ünden fazla alana yayılmış durumdadır. Bu yayılma aynı zamanda inceleme alanındaki tarım alanı ve yeşil alan varlığının oldukça azalmasına neden olmuştur. Günümüzde 400.000 den fazla nüfus ve 17 mahalleye ulaşan idari yapısıyla Ataşehir ilçesi tamamen kentsel odaklı bir yerleşim alanı konumuna gelmiştir. Ferhatpaşa, Barbaros, İçerenköy ve birkaç mahalle haricinde boş arazinin olmadığı inceleme alanı artık kentsel gelişim sürecini tamamlamış ve kentsel dönüşüm sürecindeki çalışmaların görüldüğü bir alan konumuna gelmiştir. Ulaşım ve diğer alanların varlığının da artması birçok antropojenik etkenin gelişmesini de sağlamıştır. Bütün bu arazi kullanım süreci ise kentsel gelişim ekseni, ulaşım ağları, bina 
yapı boyutu, farklı mühendislik yapıları gibi unsurlar ile rölyef üzerinde büyük değişimlerin yaşanmasına sebep olmuştur.

\subsection{Rölyef Değişim Analizi ve Antropojenik Jeomorfoloji Koşulları}

Geçmişten günümüze incelenen arazi kullanımı yapısı araştırma sahasında antropojenik etkenlerin rölyefi değiştirmede oldukça etken rol halini aldığını göstermektedir. Bu bakımdan rölyefin değişimi için analiz çalışmaları üç farklı aşamada yapılmıştır. Bunlardan ilki eski ve yeni DEM verileri üzerinden topografik analizler yapılarak oluşturulmuş, daha sonra yine DEM verilerinin karelaj sistemi üzerinden aşınım ve parçalanma şiddet derecesi analizi ile meydana getirilmiştir ve son olarak bindirme analizleri yapılmıştır. İlk olarak uygulanan topografik analizlerde rölyef değişimi; yükselti, eğim, bak1 (ana ve tüm yönler ayrı olarak), akış doğrultusu ve kurvatür durumu açısından altı farklı şekilde incelenmiştir (Şekil 7).

Uygulanan ilk aşamadaki topografik analiz sonuçlarına göre rölyef değişimin boyutlarının oldukça farklılık gösterdiği anlaşılmıştır. Yükseltinin değişim analizi verilerine göre sahanın \%18'inde rölyef değişimi gözlemlenmektedir. Değişimin dağılış boyutu ise TEM otoyolu, bağlantı yolu ile Barbaros mahallesinin kuzeyi, Atatürk, Ferhatpaşa, Mustafa Kemal, Aşık Veysel ve Kayışdağ gibi kuzey mahallelerde yoğunlaşmıştır (Şekil 7). Bu alanlarda meydana gelen değişim daha çok yerleşmenin son yıllarda yoğunlaştığı ve ana ulaşım güzergâhlarının bulunduğu alanlara tekabül etmektedir (Foto 1 ve 2). Yapılan arazi gözlemleri sonucunda yükselti değişimin morfojenetik süreçte daha çok aşındırmakazma ve tesviye-düzleştirme işlemleriyle antropojenik süreci oluşturduğu anlaşılmaktadır. Eğim analizi sonucu rölyef değişiminin ilçe alanının \% 24'ünde meydana geldiği anlaşılmaktadır. Özellikle Kurbağalıdere'nin doğu ve batısındaki mahallelerinde yoğunlaşan değişim ilçenin birçok alanında da gözlemlenebilmektedir. Ana yönlerle analiz edilen bakı durumunda inceleme alanının \%27'sinde rölyef değiş̧imi gözlenirken, tüm yönlerle yapılan analizde inceleme sahasının yarısından fazlasında değişim yaşanmıştır. Bu durum özellikle ulaşım ve yerleşim alanları için yapılan yamaç tesviyesi işlemlerin jeomorfolojik süreçteki sonucu olması kuvvetle muhtemeldir. Bu durumda doğal olarak jeomorfolojik görünümde mikro düzeyde de olsa değişimlere yol açmıştır. Akış doğrultusu, inceleme alanında \%35'lik bir oranda geçmişten günümüze rölyefin değiştiği durumunu ortaya koymaktadır. Bu durum özellikle yüzeysel akışın değişmesine neden olmakta ve tesviye-düzleştirme işlemi ile açıklanabilmektedir. Kurvatür durumu ise genel olarak sahanın mikro ölçekli arızalı yapısının değişmediğinin ama geçmişten günümüze yüzey büküklüğü dağılışının değiştiğinin göstergesidir. Muhtemelen küçük topografik çukurlukların biriktirme, hafif yükseltilerin aşındırma gibi morfojenetik süreçlerle şekillendirilmesi jeomorfolojik analizlere de yansımıştır. Yapılan topografik analizler sonucu inceleme alanında farklı rölyef değişimlerinin yaşandığı anlaşılmaktadır (Şekil 7). Yükselti ve eğim açısından yaşanan değişimlerin muhtemelen aşındırma, biriktirme ve düzleştirme süreçlerinin ortak etkisinde geliştiği sonucuna varılabilmektedir. Diğer analizlerde ise daha çok düzleştirme işleminin ön planda olabileceği, bununda doğal olarak topografya üzerinde mikro ölçekli rölyef değişimini meydana getireceği durumunu ortaya çıkarmaktadır. 

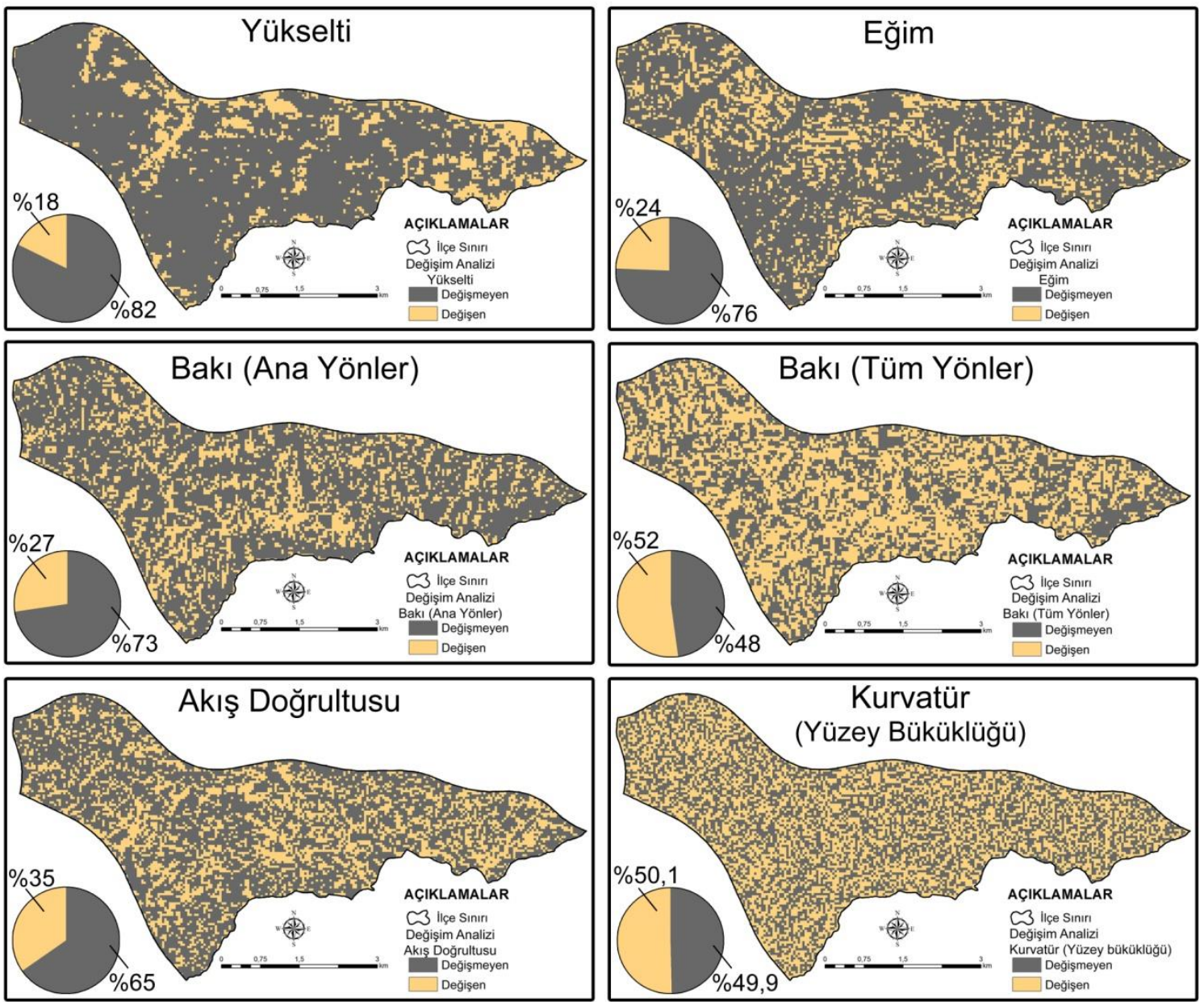

Şekil 7. Topografik Analiz Kapsamında Rölyef Değişimi Haritaları ve Oransal Değişim Verileri
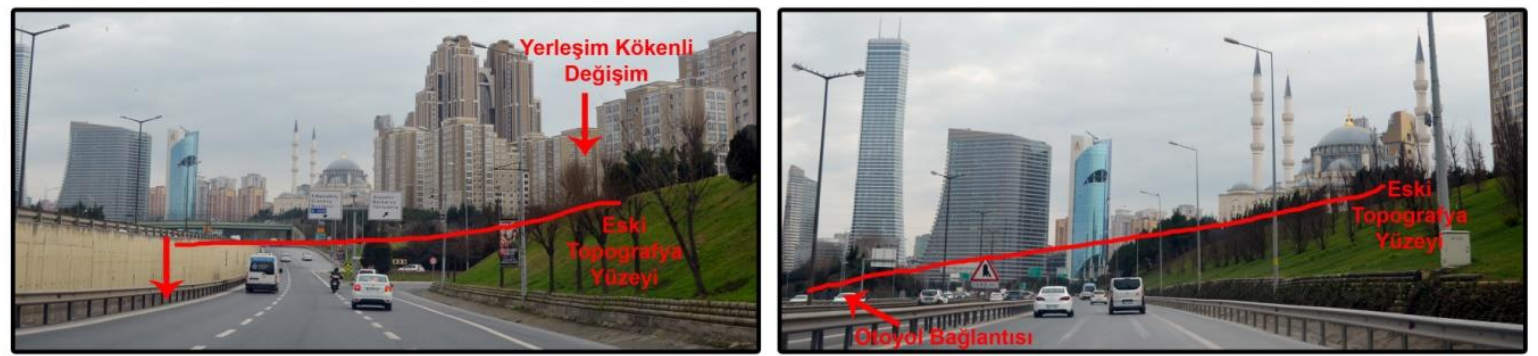

Foto 1. Barbaros Mahallesi Otoyol Bağlantısındaki Yerleşim ve Ulaşım Kökenli Rölyef Değişimleri

İnceleme sahasının eski ve yeni DEM verilerinin karelaj sistemi ile $0,25 \mathrm{~km}^{2}$ 'lik karelere bölünmesi, bu alandaki en alçak, en yüksek noktaların ve irtifa farkının (yarılma derecesi) elde edilmesiyle aşınım parçalanma şiddet derecesi ortaya konulmaktadır (Şekil 8). Karelajların orta noktasına verilen değerlerin enterpolasyonu ile elde edilen verilerin analizi rölyef değişimin detaylı boyutlarını yansıtmaktan uzak olsa da genel çerçevesini ve dağılışının sınırlarını anlatması açısından oldukça önemli veriler sağlamaktadır. 

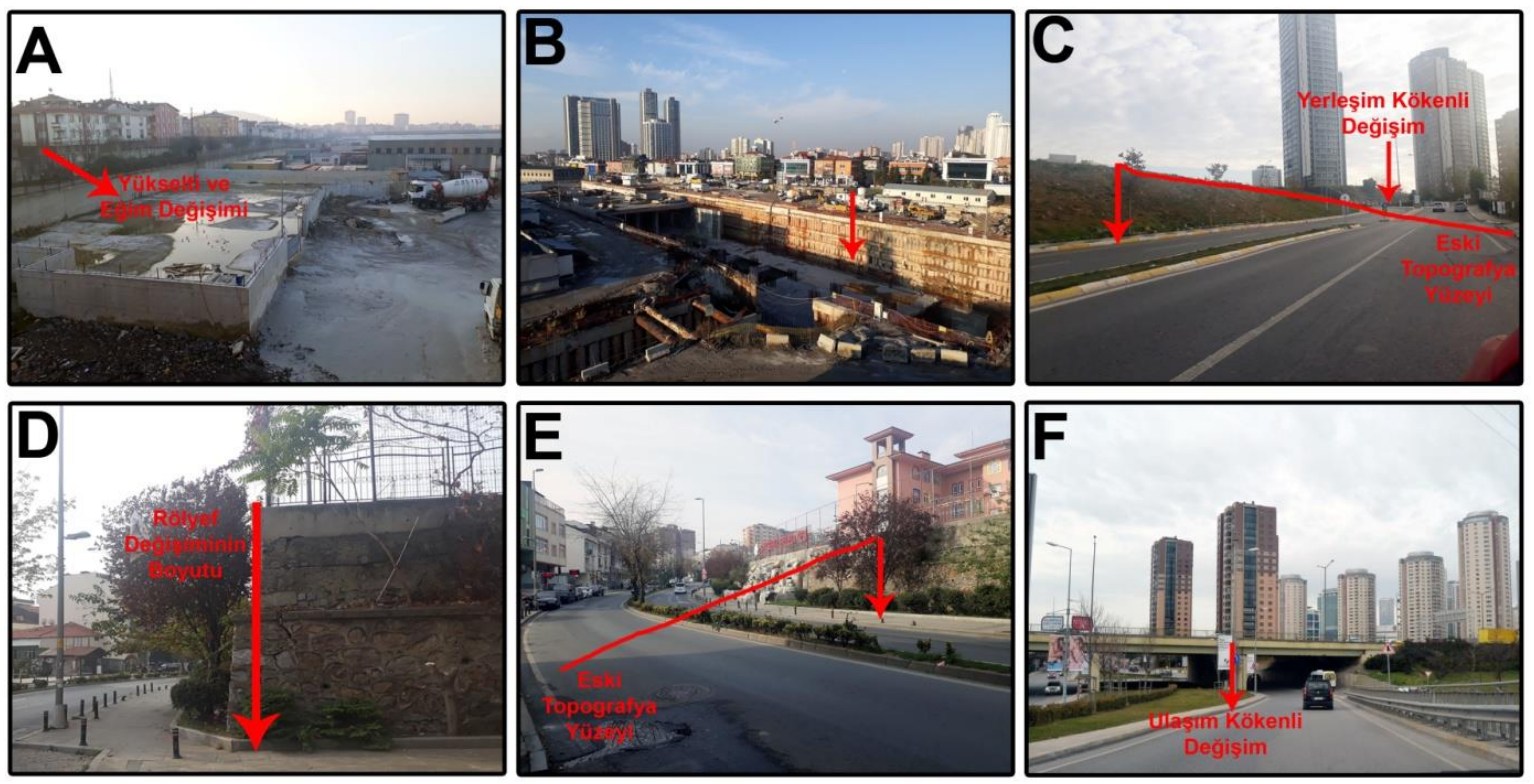

Foto 2. Rölyefin Değiştiği Alanlara Örnekler A) Ataşehir-Gümrük Sahası, B) Kayışdağ Metro İnşaat Sahası, C) Küçükbakkalköy Şerifali Caddesi, D) ve E) Fetih Mahallesi, F) Barbaros-Küçükbakkalköy Mahallesi Sınırı
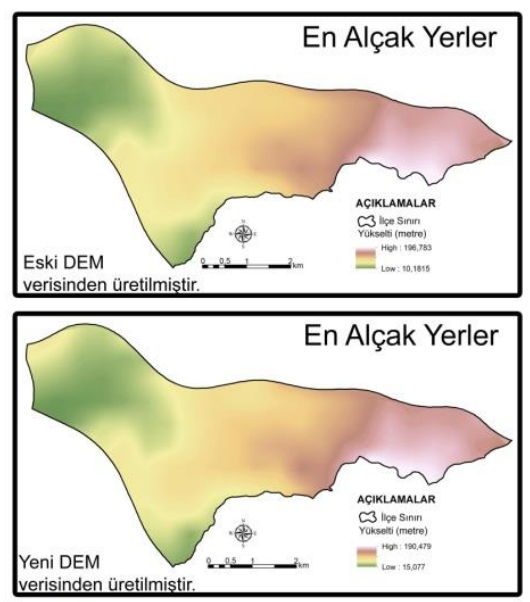

Değişim Analizi

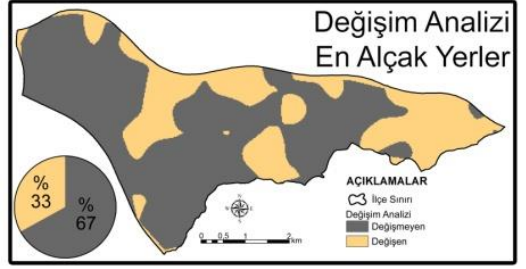

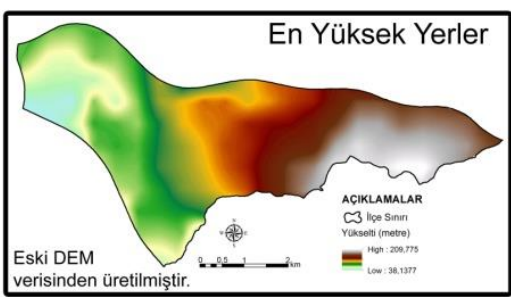
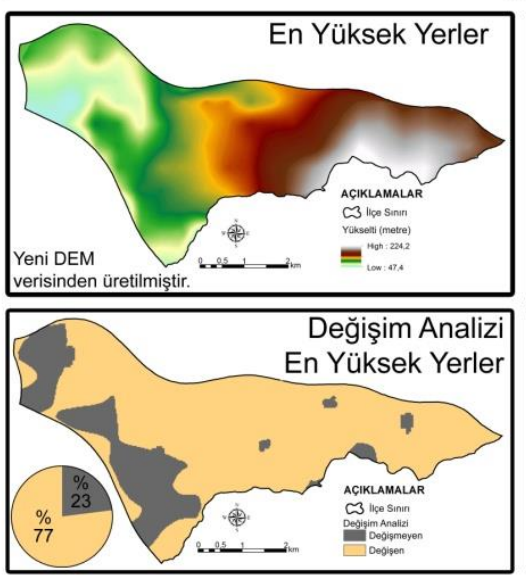
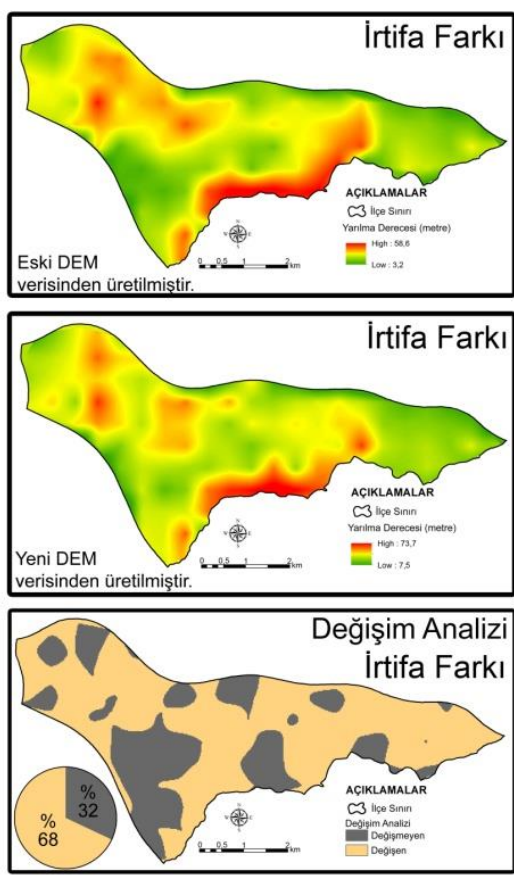

Şekil 8. Aşınım Parçalanma Şiddet Derecesi Verileri Rölyef Değişim Analizi (En Alçak, En Yüksek Yerler ve İrtifa Farkı)

Yapılan analiz sonucunda en alçak yerlerin rölyef değişimi açısından durumu, ilçe alanının \%33'ünde değişim yaşandığı şeklindedir. Verilerin dağılışına bakıldığında ise özellikle TEM bağlantı yolu, Barbaros ve Atatürk mahallelerinin kuzey kesiminde yaşanan değişim, bu alanlarda aşındırma ya da biriktirme faaliyetinin olduğu sonucunu ortaya çıarmaktadır (Şekil 8) (Foto 3 ve 4). Antropojenik etkenlerin dinamik süreçte etkili olduğu diğer alan ise ilçenin doğusunda tesviye-düzleştirme şeklinde meydana gelmekte ve doğal olarak en alçak alanların değişimine yol açmaktadır. En yüksek alanların 
analizleri rölyef değişimin oldukça geniş bir alanda meydana geldiğini ortaya çıkarmaktadır. İçerenköy, Yenisahra, Örnek, Fetih ve Barbaros mahallelerinin güney kesimleri hariç ilçe alanın \% 77'sinde rölyef değişiminin yaşandığı görülmektedir (Şekil 8). Yani karelaj alanı içerisinde en yüksek noktanın ya kazılarak değiştirildiği ya da tesviye ile düzleştirildiği durumu ortaya çıkmaktadır. İrtifa farklarının analizinde ise sahanın \% 68'inde rölyef değişiminin meydana geldiğini göstermektedir. Özellikle yapılan kazma ya da tesviye işlemleri doğal olarak irtifa farkını değiştireceğinden antropojenik etkenlerin dağılışı hakkında bilgi sahibi olmamızı sağlamaktadır. Yapılan analiz sonucu ilçenin ilk yerleşim alanlarında rölyefin çok az ya da hiç değişmediği ancak 1990'l1 yıllardan sonra yerleşim alanının genişlemeye başladığı ve doğal olarak ulaşım hatlarının da yoğunlaştığı sahalarda rölyefin oldukça değiştiği anlaşılmaktadır.
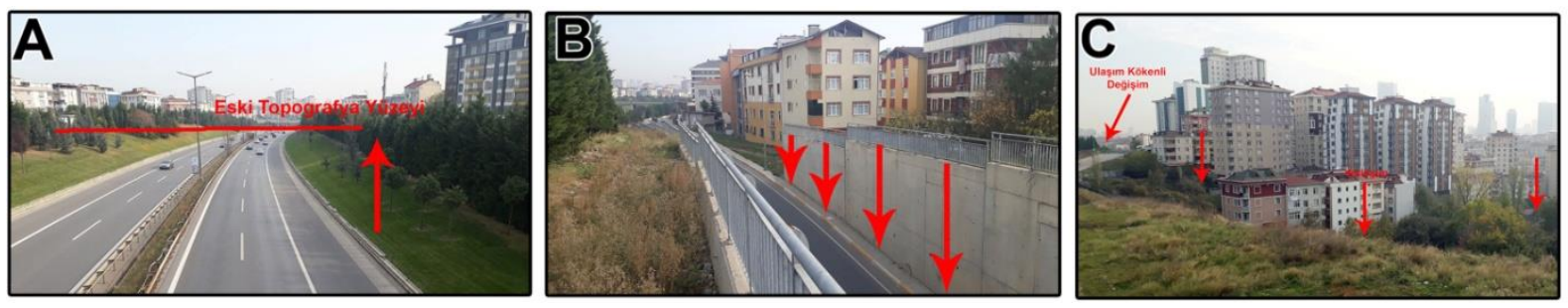

Foto 3. A) Otoyol Bağlantısındaki Rölyef Değişimi, B) Esatpaşa'da Ulaşım Kökenli Rölyef Değişimi, C) Aşık Veysel Mahallesinde Yerleşim ve Ulaşım Kökenli Topografik Yüzeyin Değiştiği Sahalar

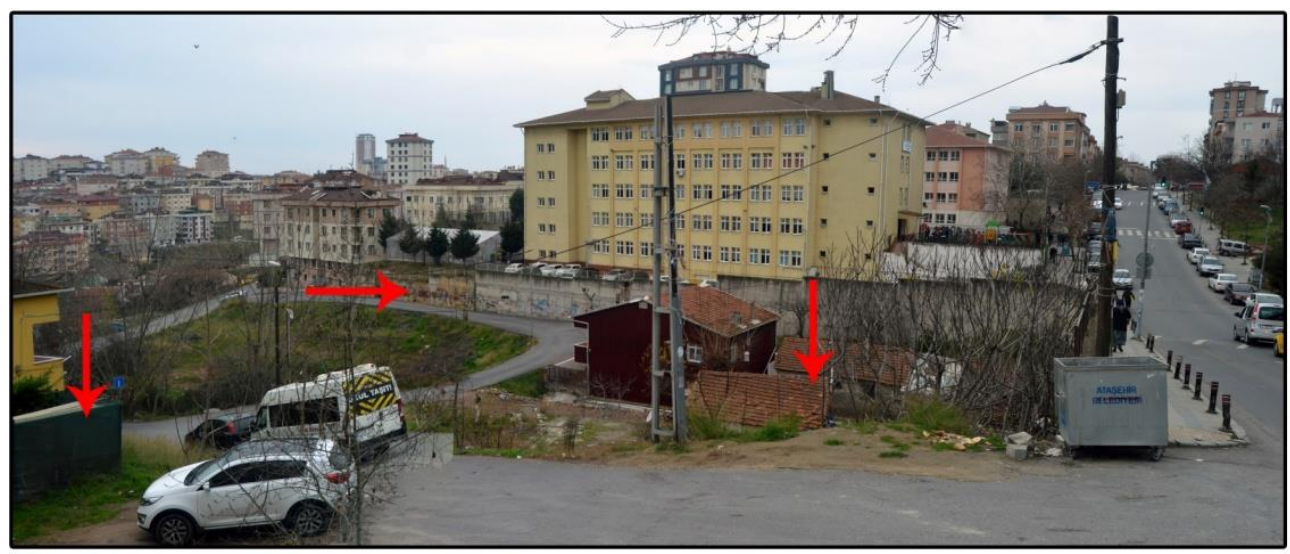

Foto 4. İnönü Mahallesinde Rölyef Değişimi

Yapılan topografik analizler ve aşınım parçalanma analizlerinin bindirme ile birleştirmesi sonucu ortaya çıkan veriler rölyefin değişiminin yorumlanmasına farklı bir bakış açısı getirmektedir (Şekil 9). Yükselti-Eğim (YE) bindirme analizi sonucu ilçe alanının \%39'unda değişim tespit edilmiştir. Değişimin yoğunlaştı̆̆ alanlar daha çok TEM otoyolu çevresinde gözlemlenmektedir. Diğer bindirme analizlerinde ise değişim oranı daima ilçe alanının yarısından fazlasında görülmüştür. Bu durum rölyef değişiminin mikro ve makro ölçekli olmasıyla birçok faktörü etkilendiğinden antropojeomofolojik koşulların değişmesi doğal olarak dinamik morfolojik yapının tamamında etkili olmaktadır. Ayrıca ulaşım için yapılan tesviye-düzeleştirme işlemleri, yerleşim alanı için oluşturulan aşındırma faaliyeti veya alan düzeltmesi için yapılan mikro ölçekli biriktirme işlemi bile sahada değişimin varlığını ortaya çıkarmaktadır. 

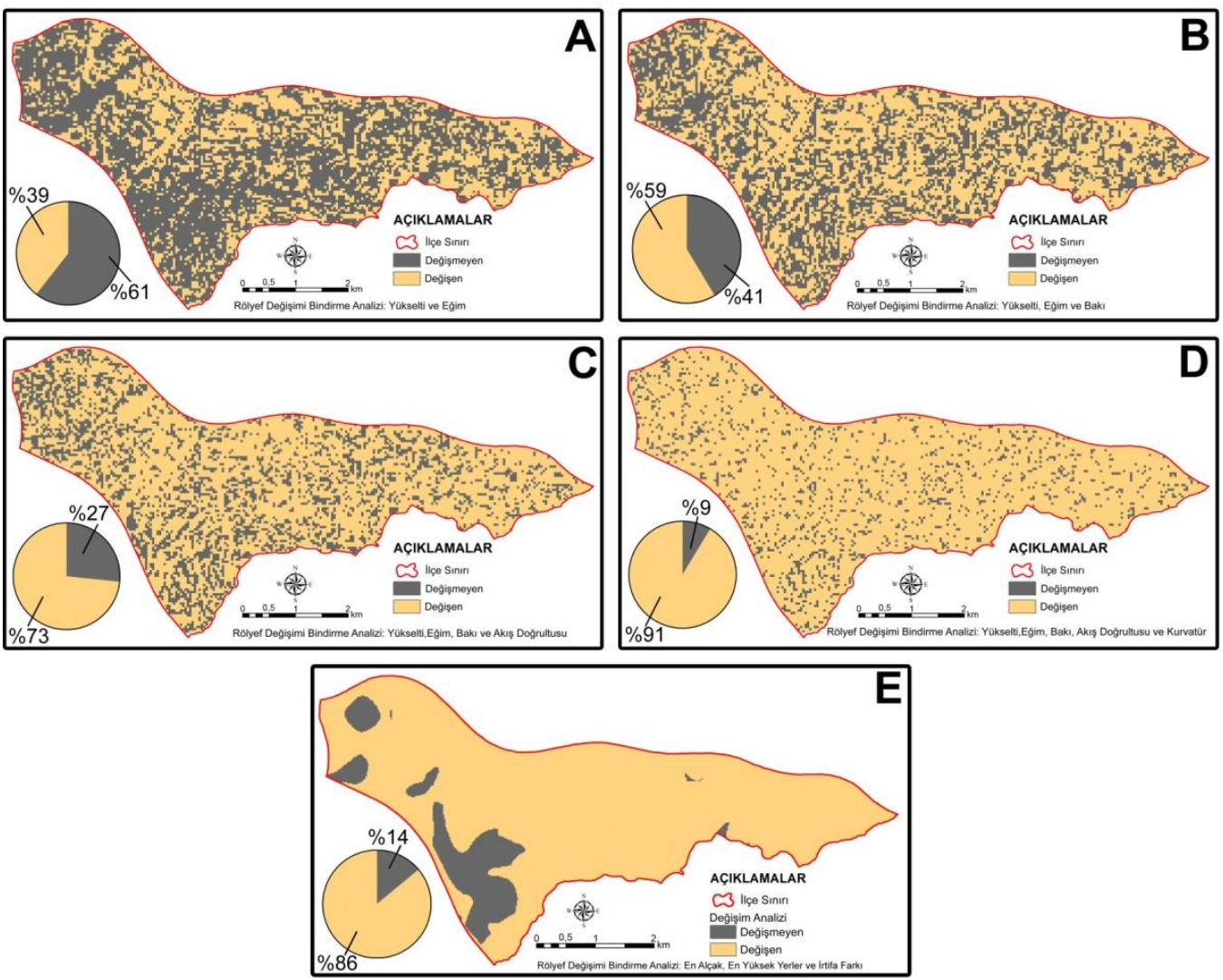

Şekil 9. Rölyef Değişiminin Bindirme (Overlay) ile Oluşturulan Analiz Haritaları A) Yükselti ve Eğim (YE), B) Yükselti, Eğim ve Bakı (YEB), C) Yükselti, Eğim, Bakı ve Akış Doğrultusu, D)Yükselti, Eğim, Bakı, Akış Doğrultusu ve Kurvatür Derecesi, E) Aşınım Parçalanma Derecesi Analizi (En Alçak, En Yüksek ve İrtifa Farkı)

İnceleme alanında yapılan bütün analiz verileri değerlendirilmiş, geçmiş ve günümüz uydu görüntüleri ile arazi çalışmaları sonucu gözlem ve ölçüm verilerine dayanan anatropojeomorfolojik rölyef değişim haritası oluşturulmuştur (Şekil 10A). Diğer yapılan analizler gibi bu haritaya da uygulanan rölyef değişim analizi sonucu Ataşehir ilçesinin \%29'luk alanında rölyef değişimi gözlemlenmiştir (Şekil 10B). Değişimin dağılış analizine bakıldığında daha çok Barbaros, Atatürk, Ferhatpaşa, Küçükbakkalköy ve Yenişehir mahallelerinde yoğunlaştığı gözlemlenmektedir. Aynı zamanda değişimin gözlemlenebilir olarak yoğunlaştığı sahalar dikkat çekici şekilde ana ulaşım güzergâhları ve yakın çevresi ile yüksek katı binaların olduğu sahalarda yer almaktadır (Foto 5).
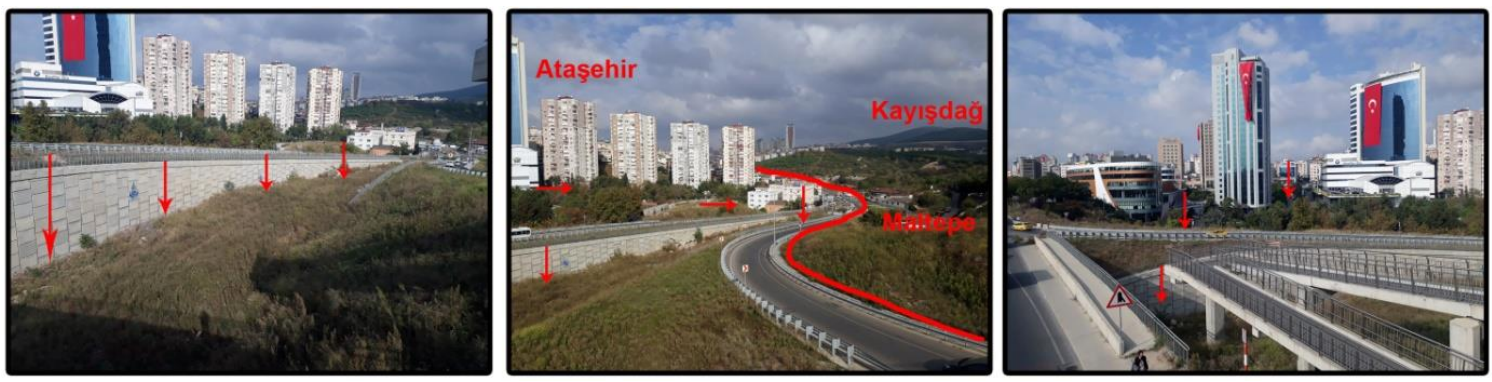

Foto 5. İçerenköy Mahallesi D-100 Karayolu Kesiminde Yerleşim ve Ulaşım Kökenli Rölyef Değişimi 


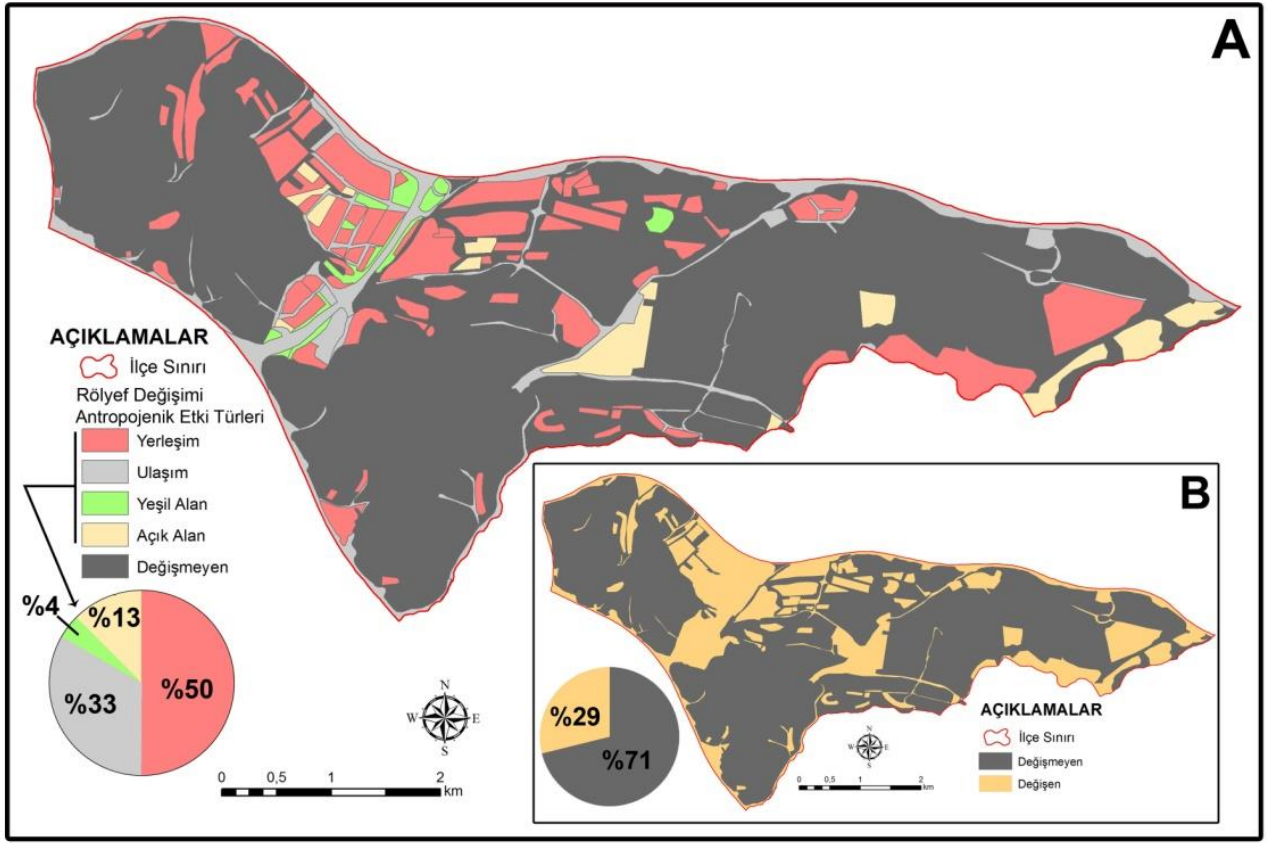

Şekil 10. A) Arazi Gözlem Sonucu Oluşturulan Antropojenik Etki Kapsamlı Rölyef Değişim Haritası B) Gözleme Dayalı Rölyef Değişim Analiz Haritası ve Oransal Verileri

Gözleme dayalı rölyef değişim haritasında, değişimin temel nedenlerinin yerleşim alanı ve ulaşım odaklı antropojenik süreçlerle meydana geldiği anlaşılmaktadır (Şekil 10A). Özellikle ulaşım odaklı değişim ana yol güzergâhları olan D-100, TEM otoyolu ve bağlantı yolunda makro düzeyde meydana geldiği ve genel morfojenetik sürecin aşındırma-kazma faaliyeti olduğu gözlemlenmiştir (Foto 6-7). Antropojeomorfolojik koşullar kapsamında; yerleşim odaklı değişim alanlarında tesviyedüzleştirme faaliyetleri temel sürecini meydana getirmektedir. Aynı zamanda bu alanlarda aşındırma ve biriktirme süreçlerinin tesviye işlemine katkı sağladığı ve topografik arızanın yoğun olduğu alanlarda temel morfojenetik süreci de oluşturduğu anlaşılmaktadır. Açık alanlar ise daha çok ilçenin kuzeydoğusunda Kayışdağ Mahallesi Gümrük işletme alanı ile Ferhatpaşa Mahallesi Kayışdağ yamaçlarında yoğunlaşmıştır. En az etkide bulunan yeşil alanların etkisi daha çok ulaşım odaklı değişimde meydana getirilen peyzaj düzenleme alanlarında etkisini göstermektedir. Elde edilen bulguların dışında arazide gözlemlenemeyen değişimlerinde olduğu aşikârdır. Bu bakımdan temel olarak yerleşim sahalarında mikro ölçeklide olsa rölyef değişimlerinin olduğu kuvvetle muhtemeldir.
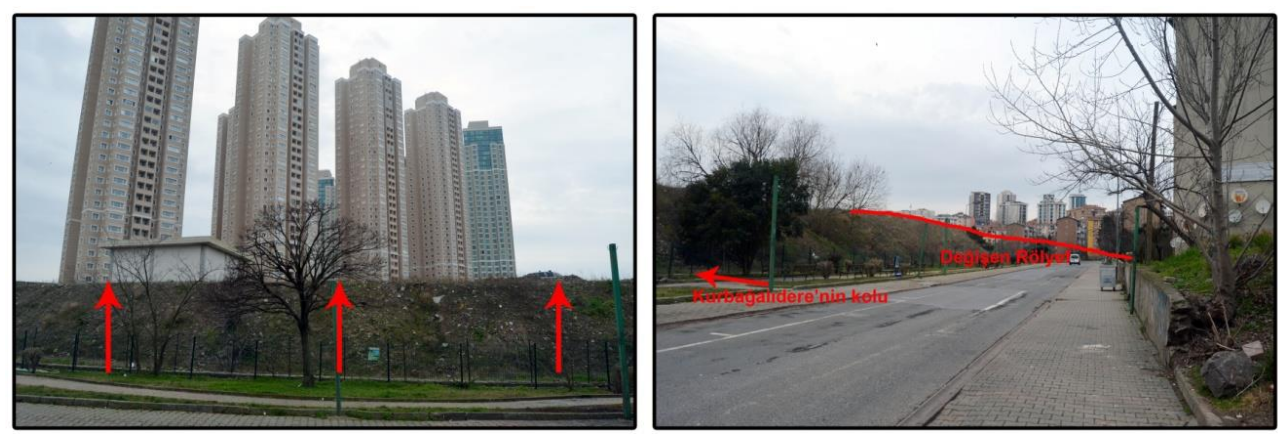

Foto 6. Atatürk Mahallesinde Yüksek Katlı Binalar ve Meydana Gelen Topografik Değişim Alanları 

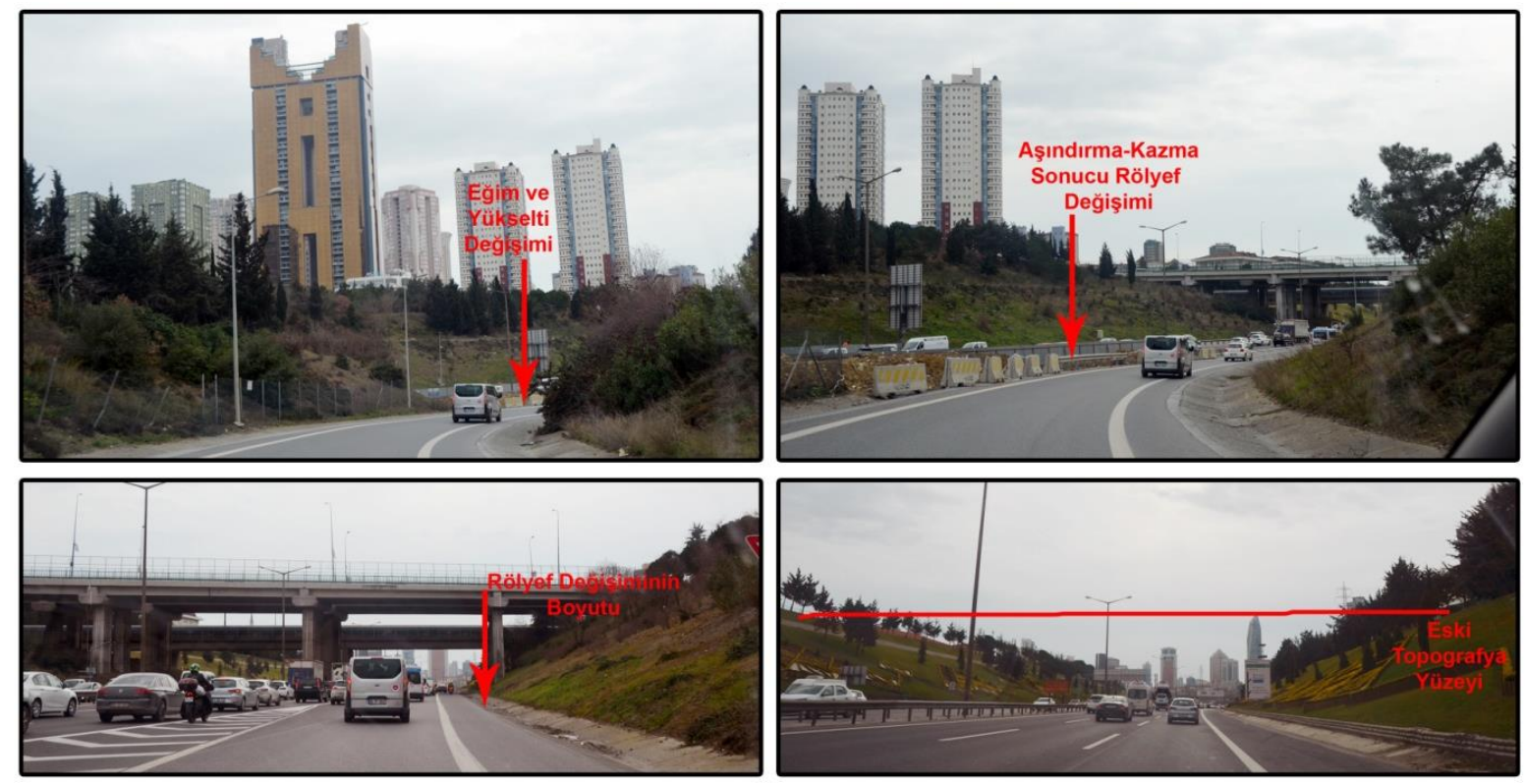

Foto 7. TEM Otoyolu ve Bağlantı Yolunda (Barbaros ve Atatürk mah.) Meydana Gelen Topografik Değişimler

\subsection{Rölyef Değişimi Antropojenik Faktör İliş̧kisinin Etki-Sonuç Analizi}

İnceleme alanındaki yoğun yerleşim sahası ve doğal ortamın azlığı elde edilen bulguların arazide tespit edilmesini zorlaştırırken değişimin tamamen gözlemlenmesinin önüne geçmektedir. $\mathrm{Bu}$ nedenle elde edilen bulgularla ortaya konan değişimlerin hangi antropojenik etkiler çerçevesinde şekillendiği ve hangi unsurun değişimde daha çok rol oynadığının tespit edilmesi gerekmektedir. Bundan dolayı uydu görüntüleri, arazi çalışmaları, noktasal ölçümler, altlık haritalar ve bütün unsurların CBS yardımıyla oluşturulan enterpolasyon verileri kullanılarak antropojenik etki analizi yapılmıştır.

İlçede antropojenik jeomorfoloji kapsamında rölyefin değişimine neden olan insan kaynaklı faaliyetler; arazi kullanımı, şehirsel gelişim alanları, bina kat sayısı yoğunluğu, ulaşım yoğunluğu ve yol genişliği yoğunluğu olarak haritalandırılmış ve kantitatif analizleri ile değerlendirilmiştir. Bu bakımdan çalışma alanında günümüz (2020) arazi kullanımın büyük bir bölümünü yerleşim alanları meydana getirmektedir. Ayrıca bu alanlar D-100, TEM otoyolu ve bağlantı yolu kesimi ile Ferhatpaşa mahallesinin Maltepe sınırı ile Örnek-Yenisahra mahalleri sınırını oluşturan Kurbağalıdere hariç ilçe alanının bütün kesimine dağılmıştır (Şekil 11A). Şehirsel gelişim alanı olarak ilçe daha çok 1990'lardan sonra yoğun yerleşmeye maruz kalmış ve bu zamanda kentsel yerleşime açılmış alanlar daha çok yer kaplamaktadır. 1980 ve 1990'lı yıllara ait yerleşim alanları daha çok D-100 karayolu çevresinde yoğunlaşırken 2000'li yıllardan sonraki yerleşim alanları ise TEM otoyoluna yakın alanlarda yoğunlaşmıştır (Şekil 11B). Ulaşım yoğunluğunda oldukça fazla tali yolun bulunduğu Kayışdağ, Mevlana, Esatpaşa, Aşık Veysel ve Örnek mahallelerinde yoğunlaşmalar gözlemlenmektedir. Ana yol güzergahı yoğunluğu ise D-100 karayolu, TEM otoyolu bağlantısında yoğunlaşmış olarak tespit edilmiştir (Şekil 12). Yapılan ölçümlerle tespit edilen yol genişliği ise en çok TEM otoyolu ile bağlantı yolu, D-100 karayolu, Libadiye, Dudullu ve Kayışdağ caddesi yollarında yoğunlaşmıştır. 

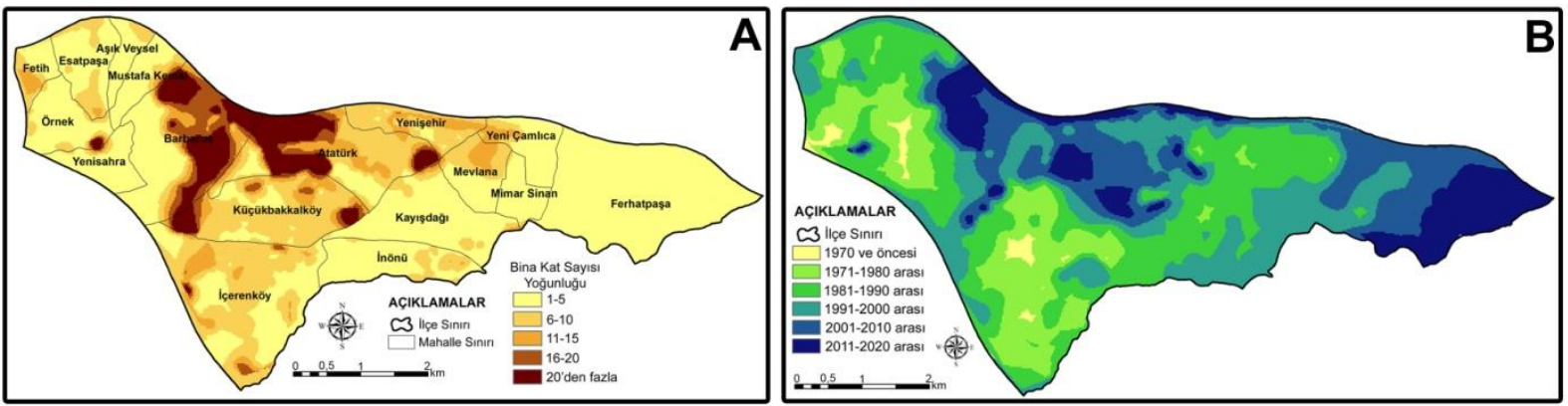

Şekil 11. A) Bina Kat Sayısı Yoğunluk Haritası B) Geçmişten Günümüze Kentsel Alan Gelişim Haritası
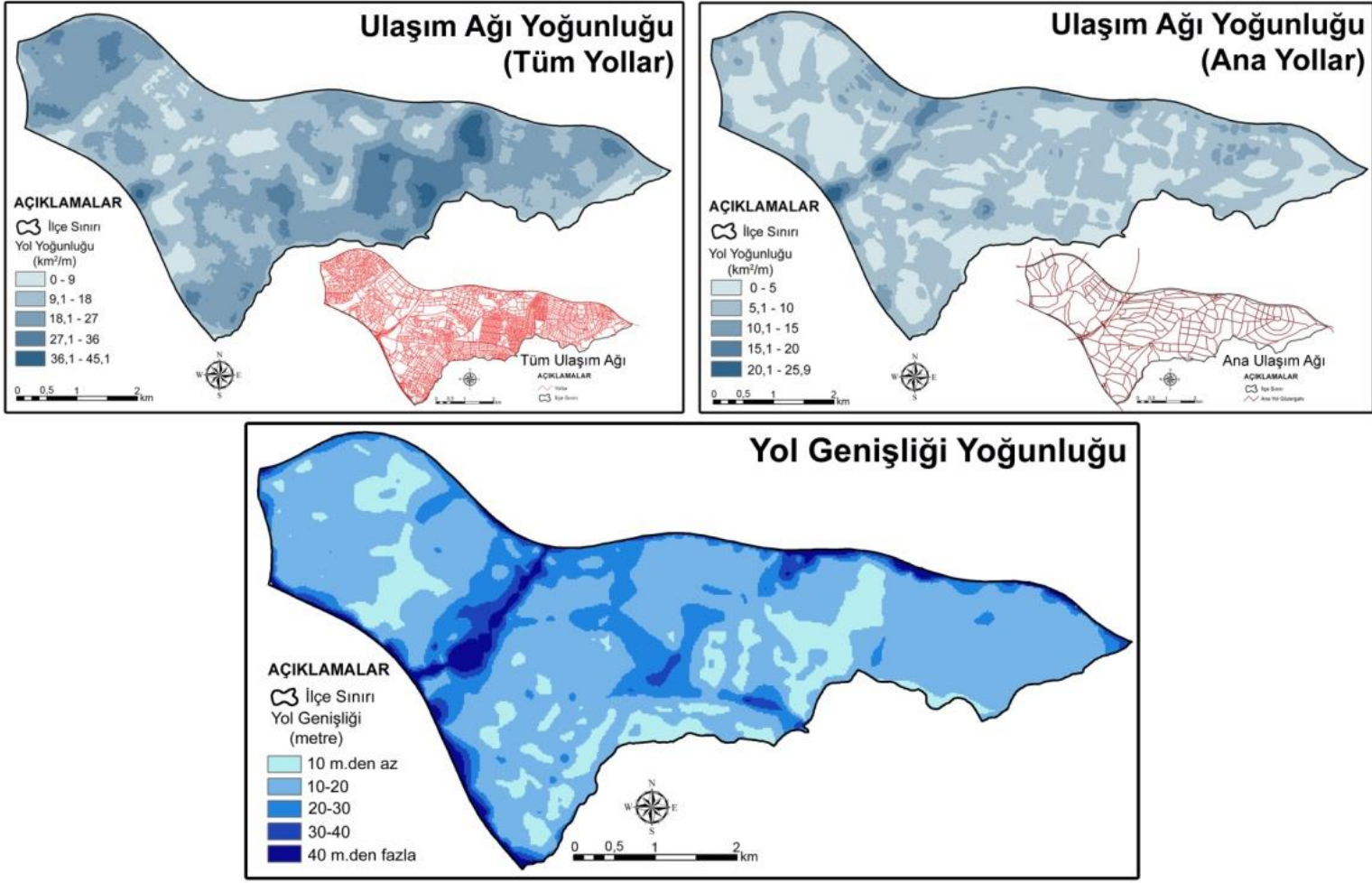

Şekil 12. Ulaşım Odaklı Antropojenik Etki Faktörleri Yoğunluk Haritaları

İnceleme sahasında meydana gelen rölyef değişiminin insan kaynaklı etki faktörlerini nedensonuç açısından iki değişkenli korelasyon analizleri ile kantitatif açıdan değerlendirilerek meydana gelen değişimin nedenleri sorgulanmıştır. Bu kapsamda rölyef değişimin çok yüksek oranlarda olmadığı ve genel olarak belli antropojenik koşullardan etkilenerek meydana geldiği saptanan dokuz farklı değişim analizi sonuçları, altı farklı antropojenik etki faktörleri ve alt parametreleri açısından alansal ve yüzdesel olarak analiz edilmiştir (Şekil 13-Çizelge 2).

Antropojenik etkilerden binaların kat yüksekliğinin rölyef değişimi açısından etki korelasyon ilişkisi değerlendirildiğinde, gözlem sonucu ve yükselti analizi ile oluşan rölyef değiş̧imi dışındaki bütün verilerde 1-5 kat arasındaki binaların rölyef değişimin \%50'sini oluşturduğu gözlemlenmektedir. Bütün analizlerin ortalama değeri de 1-5 kat için \%50'in üzerinde şeklindedir ve durumun bu şekilde oluşmasında ilçedeki bu kat yüksekliğindeki binaların geniş alan kaplaması ve topografik alanda mikro veya makro düzeyde daima bir tesviye işlemi ile rölyef değiştirmesi sonucu ortaya çıkmaktadır. Bina 
kat yüksekliğindeki analizde dikkat çeken nokta ise 10 kattan daha yüksek binaların oluşan rölyef değişimin 1/3'üne yakının nedenini teşkil etmesidir. Meydana gelen kantitatif değer bina yüksekliğinin artmasının doğal olarak rölyefin üzerinde de mühendislik açısından bazı faaliyetlerin meydana gelmesine ve rölyefin değiştirilmesine yol açtı̆̆ yorumunu yapmamızı sağlamaktadır. Özellikle ilçede Barbaros, Atatürk, Küçükbakkalköy gibi mahallerde inşa edilen çok yüksek yapıların dağılışına bakıldığında durum daha belirgin şekilde anlaşılmaktadır (Foto 8 ve 9).
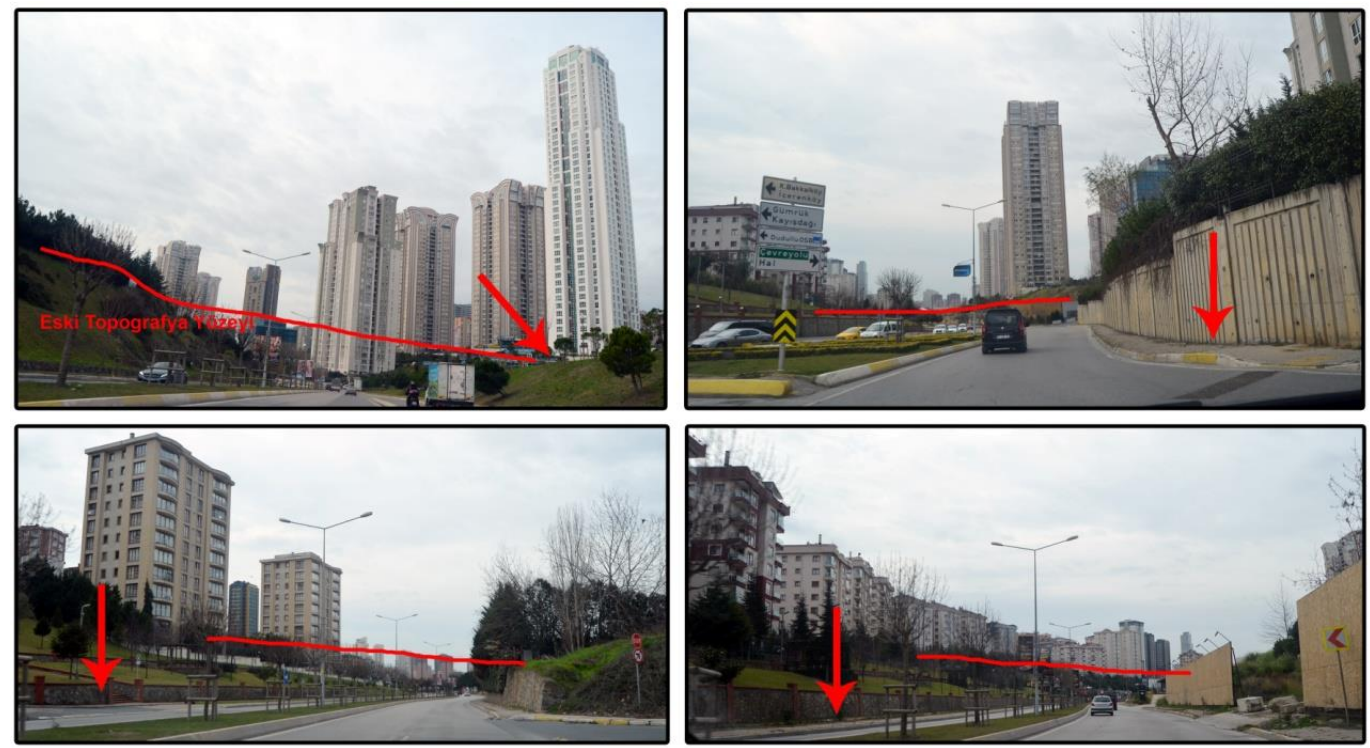

Foto 8. Atatürk Mahallesinde Yüksek Katlı Binalar ve Ulaşım Nedeniyle Oluşan Topografik Değişimler
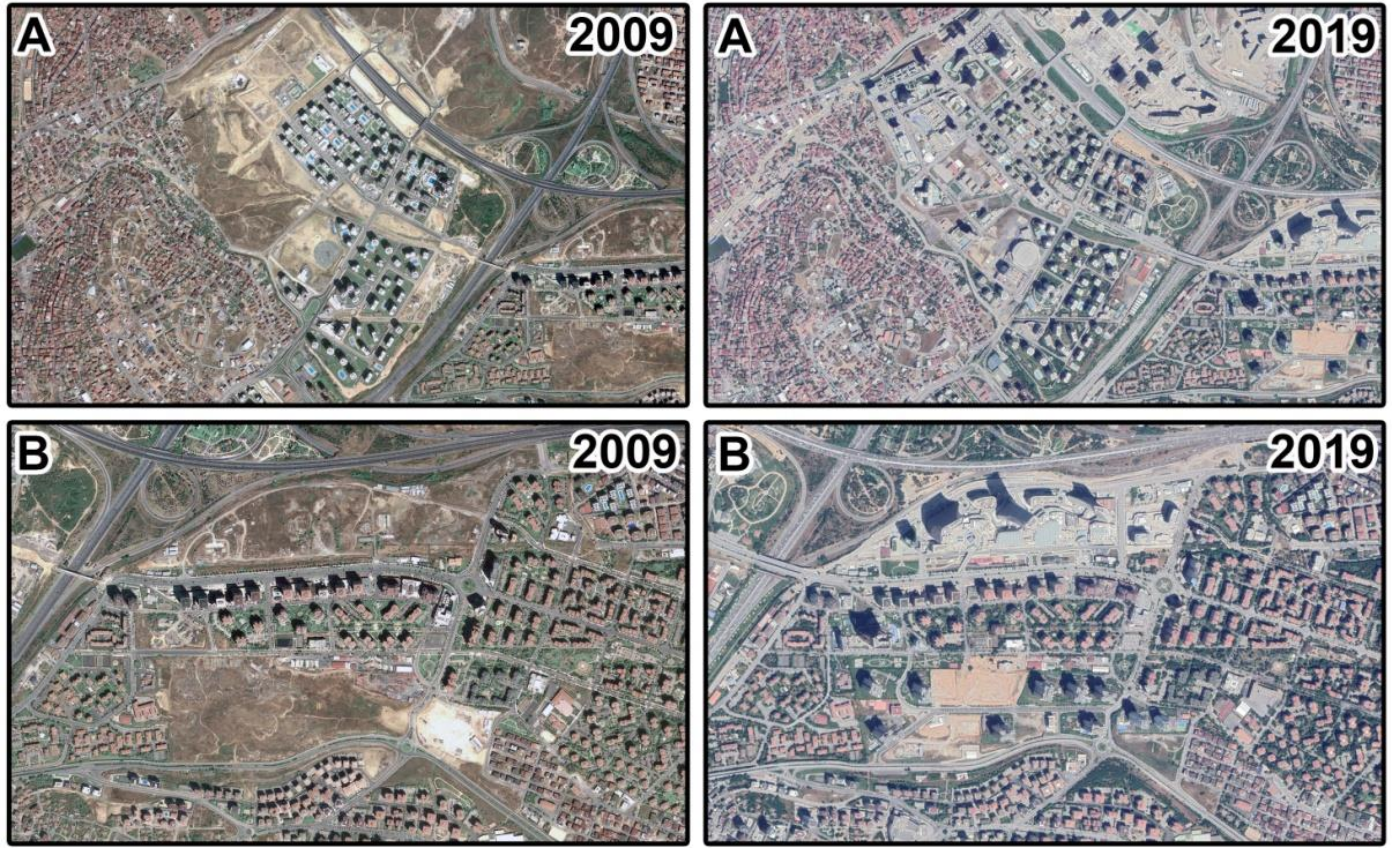

Foto 9. Son 10 Yılda Yeni Yerleşim Alanlarının Etkisi ile Değişen Rölyef A) Barbaros Mah. B) Atatürk Mah. 

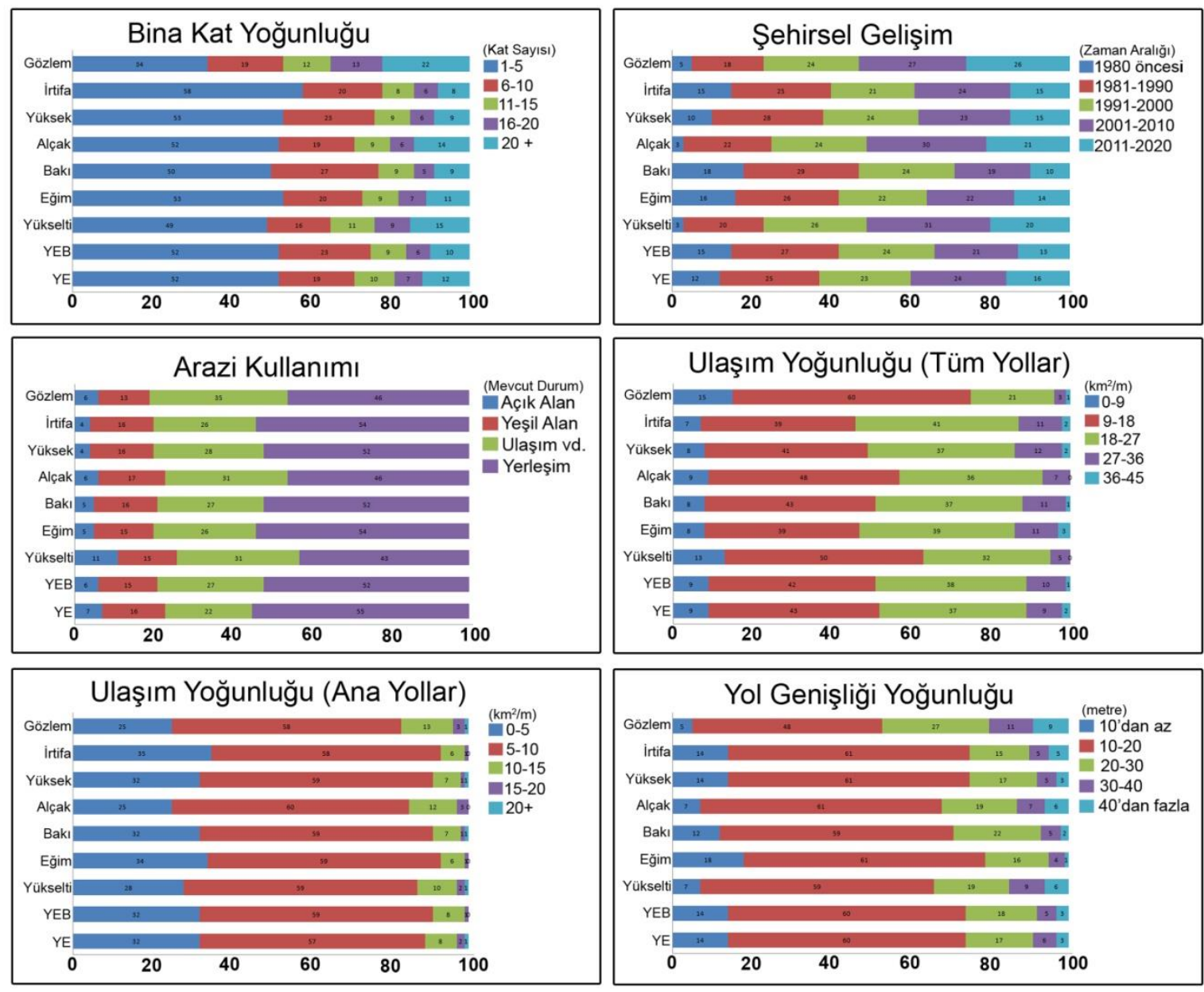

Şekil 13. Rölyef Değişimi-Antropojenik Etki Faktörleri Oransal (Yüzdelik) Korelasyon Grafikleri

İlçede tarihsel açıdan şehirsel gelişimin rölyef değişimine etkisinin incelendiği analiz sonuçları, genel olarak 1990'dan sonra meydana gelen kentleşme sürecinin rölyefin değişiminde büyük rol oynadığını göstermektedir. İnceleme sahası yaşanan şehirleşme etkeniyle meydana gelen beşeri baskılara maruz kalmış, topografik yüzey alt-üst yapı çalı̧̧malarıyla aşındırma, biriktirme ve tesviye morfojenetik süreçleriyle büyük değişimlere uğramıştır. 2000’li yıllardan sonra devam eden göç, nüfus artışı ve çok katlı bina varlığı ile dikkat çeken şehirsel gelişim aralığı rölyef değişiminin boyutsal ve oransal olarak çok fazla değişime uğradığını da göstermektedir. Yükselti, yükselti-eğim (YE) bindirme analizi, en alçak yerler ve gözlem verileri ile oluşan rölyef değişimin \% 50'sinden fazlasının oluşmasında 2000'lerden sonra meydana gelen şehirsel gelişim antropojenik faktörü etkili olmuştur (Çizelge 2).

Çalışma alanında rölyef değişimin temel nedenini oluşturan kentleşme etkeni, arazi kullanımı verileri ile de doğrulanmaktadır. Bütün verilerin ortalaması temel alındığında rölyef değişimin \%50'sini daima yerleşim kökenli antropojenik etkiler meydana getirmiştir. Arazi kullanımı açısından diğer önemli etken ise ulaşım odaklı antropojenik etkenlerdir. Bu noktada analiz sonuçlarında dikkat çeken unsur ise gözlem, yükselti ve en alçak yerler rölyef değiş̧iminin verilerinde ulaşım kökenli değişimler \% 30'üzerinde tespit edilmiştir. Bu durum özellikle dağılış açısından değişimlerin D-100, TEM ve 
bağlantı yolların olduğu alanlarda yoğunlaştığını, rölyefin hem alansal hem de boyutsal olarak büyük değişimlerde gerçekleştiğini göstermektedir. Bu alanlar aynı zamanda antropojeomorfolojik koşullar açısından yapay vadilerin oluşmasını sağlamıştır. Yeşil alanlar daha çok ulaşım yollarındaki peyzaj çalışması ve kapalı sitelerdeki alanlarda meydana gelen etkenler ile rölyef değişimine yol açmıştır.

Çizelge 2. Rölyef Değişimi-Antropojenik Etki Faktörleri ve Alt Parametreleri İliş̧ki Analizi

\begin{tabular}{|c|c|c|c|c|c|c|c|c|c|c|c|}
\hline \multicolumn{2}{|c|}{$\begin{array}{c}\text { Rölyef Değişimini } \\
\text { Etkileyen Antropojenik } \\
\text { Unsurlar ve Alt } \\
\text { Birimleri } \\
\end{array}$} & \multicolumn{10}{|c|}{ Rölyef Değişimi Analiz Türlerinin Antropojenik Etki Birimlerine Göre Yüzdesel (\%) Oranları } \\
\hline \multirow{6}{*}{ 泀 } & & YE & YEB & Yükselti & Eğim & Bak1 & $\begin{array}{l}\text { En } \\
\text { Alçak }\end{array}$ & $\begin{array}{l}\text { En } \\
\text { Yüksek }\end{array}$ & $\begin{array}{l}\text { İrtifa } \\
\text { fark1 }\end{array}$ & Gözlem & Ort. \\
\hline & $1-5$ & 52 & 52 & 49 & 53 & 50 & 52 & 53 & 58 & 34 & $\mathbf{5 0 , 3}$ \\
\hline & $6-10$ & 19 & 23 & 16 & 20 & 27 & 19 & 23 & 20 & 19 & 20,6 \\
\hline & $11-15$ & 10 & 9 & 11 & 9 & 9 & 9 & 9 & 8 & 12 & 9,5 \\
\hline & $16-20$ & 7 & 6 & 9 & 7 & 5 & 6 & 6 & 6 & 13 & 7,2 \\
\hline & 20'den fazla & 12 & 10 & 15 & 11 & 9 & 14 & 9 & 8 & 22 & 12,4 \\
\hline \multirow{6}{*}{ 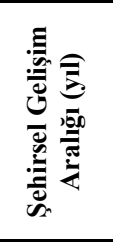 } & & YE & YEB & Yükselti & Eğim & Bak1 & $\begin{array}{l}\text { En } \\
\text { Alçak }\end{array}$ & $\begin{array}{l}\text { En } \\
\text { Yüksek }\end{array}$ & $\begin{array}{l}\text { İrtifa } \\
\text { Fark1 }\end{array}$ & Gözlem & Ort. \\
\hline & 1980 Öncesi & 12 & 15 & 3 & 16 & 18 & 3 & 10 & 15 & 5 & 10,7 \\
\hline & $1980-1990$ & 25 & 27 & 20 & 26 & 29 & 22 & 28 & 25 & 18 & 24,5 \\
\hline & $1990-2000$ & 23 & 24 & 26 & 22 & 24 & 24 & 24 & 21 & 24 & 23,5 \\
\hline & $2000-2010$ & 24 & 21 & 31 & 22 & 19 & 30 & 23 & 24 & 27 & 24,6 \\
\hline & $2010-2020$ & 16 & 13 & 20 & 14 & 10 & 21 & 15 & 15 & 26 & 16,7 \\
\hline \multirow{5}{*}{ 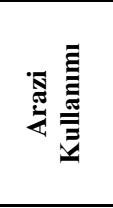 } & & YE & YEB & Yükselti & Eğim & Bak1 & $\begin{array}{l}\text { En } \\
\text { Alçak }\end{array}$ & $\begin{array}{l}\text { En } \\
\text { Yüksek }\end{array}$ & $\begin{array}{l}\text { İrtifa } \\
\text { fark1 }\end{array}$ & Gözlem & Ort. \\
\hline & Açık Alanlar & 7 & 6 & 11 & 5 & 5 & 6 & 4 & 4 & 6 & 6 \\
\hline & Yeşil Alan & 16 & 15 & 15 & 15 & 16 & 17 & 16 & 16 & 13 & 15,4 \\
\hline & Yol vd. alan & 22 & 27 & 31 & 26 & 27 & 31 & 28 & 26 & 35 & 28,1 \\
\hline & Yerleşim & 55 & 52 & 43 & 54 & 52 & 46 & 52 & 54 & 46 & 50,5 \\
\hline \multirow{6}{*}{ 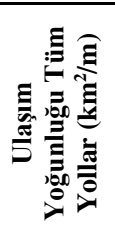 } & & YE & YEB & Yükselti & Eğim & Bak1 & $\begin{array}{l}\text { En } \\
\text { Alçak }\end{array}$ & $\begin{array}{l}\text { En } \\
\text { Yüksek }\end{array}$ & $\begin{array}{l}\text { İrtifa } \\
\text { fark1 }\end{array}$ & Gözlem & Ort. \\
\hline & $1-9$ & 9 & 9 & 13 & 8 & 8 & 9 & 8 & 7 & 15 & 9,5 \\
\hline & $9-18$ & 43 & 42 & 50 & 39 & 43 & 48 & 41 & 39 & 60 & 45,1 \\
\hline & $18-27$ & 37 & 38 & 32 & 39 & 37 & 36 & 37 & 41 & 21 & 35,4 \\
\hline & $27-36$ & 9 & 10 & 5 & 11 & 11 & 7 & 12 & 11 & 3 & $\mathbf{8 , 7}$ \\
\hline & $36-45$ & 2 & 1 & 0 & 3 & 1 & 0 & 2 & 2 & 1 & 1,3 \\
\hline \multirow{6}{*}{ 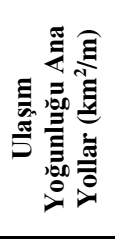 } & & YE & YEB & Yükselti & Eğim & Bak1 & $\begin{array}{l}\text { En } \\
\text { Alçak }\end{array}$ & $\begin{array}{l}\text { En } \\
\text { Yüksek }\end{array}$ & $\begin{array}{l}\text { İrtifa } \\
\text { fark1 } \\
\end{array}$ & Gözlem & Ort. \\
\hline & $0-5$ & 32 & 32 & 28 & 34 & 32 & 25 & 32 & 35 & 25 & 30,6 \\
\hline & $5-10$ & 57 & 59 & 59 & 59 & 59 & 60 & 59 & 58 & 58 & 58,7 \\
\hline & $10-15$ & 8 & 8 & 10 & 6 & 7 & 12 & 7 & 6 & 13 & 8,5 \\
\hline & $15-20$ & 2 & 1 & 2 & 1 & 1 & 3 & 1 & 1 & 3 & 1,6 \\
\hline & $20-26$ & 1 & 0 & 1 & 0 & 1 & 0 & 1 & 0 & 1 & 0,6 \\
\hline \multirow{6}{*}{ 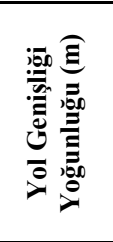 } & & $\mathrm{YE}$ & YEB & Yükselti & Eğim & Bak1 & $\begin{array}{l}\text { En } \\
\text { Alçak }\end{array}$ & $\begin{array}{l}\text { En } \\
\text { Yüksek }\end{array}$ & $\begin{array}{l}\text { İtifa } \\
\text { fark1 }\end{array}$ & Gözlem & Ort. \\
\hline & 10 'dan az & 14 & 14 & 7 & 18 & 12 & 7 & 14 & 14 & 5 & 11,7 \\
\hline & $10-20$ & 60 & 60 & 59 & 61 & 59 & 61 & 61 & 61 & 48 & 58,8 \\
\hline & $20-30$ & 17 & 18 & 19 & 16 & 22 & 19 & 17 & 15 & 27 & 18,9 \\
\hline & $30-40$ & 6 & 5 & 9 & 4 & 5 & 7 & 5 & 5 & 11 & 6,4 \\
\hline & $40>$ & 3 & 3 & 6 & 1 & 2 & 6 & 3 & 5 & 9 & 4,2 \\
\hline
\end{tabular}

Rölyef değişimine neden olan antropojenik etkenlerden ulaşımın tüm ve ana yollar açısından analizine bakıldığında yoğunluğun en az olduğu ya da ikinci sırada olduğu alanlar değişimde temel etken olmuştur. Bu durum özellikle şehirsel gelişme ile oluşan mahallelerde yapılan üst yapı ulaşım çalışmaları ve daha çok tesviye-düzleştirme morfojenetik süreciyle açıklanmaktadır. Ancak buradaki dikkat çekilmesi gereken nokta hem tüm yollar hem de ana yollar için yoğunluğun az olduğu alanlar ilçe 
sınırları içerisinde daha geniş alan kapladığı için korelasyon analizinde temel etken olarak gözükmektedir. Yapılan arazi çalışmaları ise alansal olarak çok fazla rölyef değişimine etki etmeyen yoğun alanların boyutsal açıdan ise en büyük etkiye neden olan sahaları meydana getirdiği tespit edilmiştir. Özellikle Barbaros ve Atatürk mahalle sınırını meydana getiren TEM bağlantı yolu 50 m.ye varan boyutlarda aşındırma değişimi ile gözlemlenmiş ve bu alanda yapay bir jeomorfolojik vadi meydana gelmiştir (Foto 7). Burada belirtilen durum yol genişliği yoğunluğu içinde geçerlidir. Yoğunluğun 10-20 ve 20-30 m arasında olduğu sahalar daha geniş yer kapladığı için tesviye-düzleştirme ile rölyef değişimine neden olan en büyük alt parametreyi meydana getirmektedir. Ancak 40'm'den daha geniş yollar ise alansal olarak çok yer kaplamasa da boyutsal olarak büyük değişimler oluşturmuş ve antropojeomorfolojik birimlerin temelini inceleme alanında meydana getirmiştir.

Korelasyon analizi ve neden sonuç analizleri genel olarak değerlendirildiğinde, bütün unsurlar rölyef üzerinde değişimlere yol açmış ve bazı alanlarda yapay yüzey şekilleri ortaya çıkmıştır. D-100 karayolu, TEM otoyolu ve bağlantı yolları ulaşım etkeniyle yükseltinin en çok değişime uğramasına neden olan temel faktördür. Özellikle aşındırma faaliyetin morfojenetik süreçte görüldüğü sahalarda yükseltinin 40 m.den fazla değiştiği alanlar meydana gelmiştir. Bunun dışında Barbaros Mahallesi kuzeyi, Atatürk Mahallesinde yapılan çok katlı binalar ve yeni yerleşim alanları arızalı yüzeyin aşındırma ve düzleştirme faaliyeti ile yeniden şekillendirildiğini göstermektedir. Eğim değerleri ise yerleşim ve ulaşım alanları için yapılan düzleştirme faaliyeti nedeniyle belli alanlarda yoğunlaşmıştır. Ancak bu alanların beşeri baskı etkisinden çok eğim değerinin diğer alanlara göre yüksek olmasından dolayı değişime uğradı sonucu ortaya çıkmaktadır. Bu durumda sahada doğal ve beşeri faktörlerin ortak etkisinde antropojeomorfolojik koşulların ortaya çıtığını göstermektedir. Bakı (ana yönler) değişimin ulaşım ağıyla paralel olarak değiştiği ancak tüm yönler temel alındığında değişimin bütün antropojenik faktörlerden etkilendiği anlaşılmaktadır. İrtifa farkı analizlerinde en alçak yerlerin değişim analizinin bina kat sayısının fazla olduğu, şehirsel gelişimin günümüze yakın olduğu, ana yol güzergahlarının ve yol genişliğinin fazla olduğu alanlarda yoğunlaştı̆̆ ortaya çıkmaktadır. Özellikle ulaşım ve yüksek katlı binalar için yapılan antropojeomorfolojik süreçlerin aşındırma ve tesviye faaliyeti olması bu alanlarda en alçak noktaların daha da derine kazma işlemi ile değiştiğini göstermektedir. Yüksek alanlar ve irtifa farkı analizleri ise bütün antropojenik faktörlerden etkilenmesi, ilçe alanının en eski yerleşim yerleri dışındaki çoğu alanda tesviye-düzleştirme işleminin gerçekleştiğini ortaya koymaktadır. Elde edilen bütün bulgular inceleme sahasında belirtilen beşeri faaliyetlerin mikro ve makro ölçekte, geniş ve dar alanlı olarak mutlak suretle rölyef üzerinde değişimler oluşturduğunu göstermektedir. Bu durumda da sahanın tamamının yerleşim alanı olması ve beşeri faaliyetlerin oluşturacağı değişim talebiyle topografik görünüm tekrar tanzim edilmiş ve antropojeomorfolojik koşullar meydana gelmiştir.

\section{Sonuç}

Nüfusun hızla artması, şehirlere olan yoğun göç, gelişen teknolojik imkanlar ve insanların artan talepleri sonucu, doğal koşullar daima beşeri kullanımlara, baskılara ve değişimlere maruz kalmaktadır. Özellikle jeomorfolojik koşullar, etkisi ve baskısı genişleyen beşeri faaliyet alanından büyük ölçüde etkilenmekte, çeşitli morfojenetik süreçlerle birlikte farklı boyut ve yapılarda rölyef değişiminin yaşanmasına da neden olmaktadır. İstanbul gibi yoğun nüfus alanlarındaki yerleşme, ulaşım, sanayi faaliyetleri ve diğer beşeri etkenlerin yanında yapılan mega projeler antropojenik jeomorfoloji 
unsurlarının ortaya çıkmasını sağlarken daima topografik görünümde değişimlere yol açmaktadır. Yaşanan değişimler ise eski ve yeni topografik verilerle tespit edilebilmekte, dağılışları, boyutları ve etki nedenleri sorgulanabilmektedir. Ataşehir örneğinde CBS'nin etkin kullanımı ile yapılan rölyef değişim analiz çalışması ise farklı antropojenik etkenler nedeniyle rölyef üzerinde birçok değişimin yaşandığının tespit edilmesini sağlamıştır. Çalışmada yapılan rölyef değişimi analizleri üç farklı aşamada (topografik analiz, aşınım-parçalanma analizi ve bindirme analiz) uygulanmış ve birçok değişim sonucu ortaya konmuştur. Özellikle yükselti ve eğim analizlerinin antropojenik etkenlerden yerleşim ve ulaşım alanlarıyla olan ilişkisi, ilçenin antropojenik jeomorfoloji yapısını ortaya koyarken rölyef değişiminin temel nedenlerine de açıklı getirmiştir. Ataşehir'in arazi kullanım durumu, şehirsel gelişimi, bina kat sayısı yoğunluğu ve ulaşım yapısı gibi temel antropojenik etkenler topografik görünümünün neredeyse ilçenin her noktasında mikro ve makro ölçekli olarak değişmesine neden olmuştur. Özellikle D-100 karayolu, TEM otoyolu ve bağlantı yolu yükselti ve eğim açısından birçok morfojenetik süreci etkileyerek arazide boyutsal olarak büyük değişimlere yol açmıştır. Son 15 yıllık süreçte ise yapılan yüksek katlı binaların oluşturduğu mühendislik çalışmaları da arazinin tanzim edilmesine yol açmış ve rölyef aşındırma-kazma süreci ile değişime uğramıştır. Yapılan arazi gözlemlerinde rölyef değişiminin sadece \% 30'luk bölümünün gözlenebilmesi ise artık arazinin doğal yapısının tamamen değiştiğinin ve morfojenetik süreçte antropojenezin asıl rolü üstlendiğini göstermektedir. Çalışmanın temel varsayımı olan antropojenik etkenlerin rölyefi değiştirdiği koşulu yapılan analizler, üretilen haritalar, arazi gözlemleri ve etki-neden-sonuç korelasyon analiz ile doğrulanmıştır. Çalışmada daha detaylı tekonolojik imkanların kullanılamamasından dolayı sahada rölyef değişiminin tam doğruluk oranını yansıtmada sorunlar olduğu da tespit edilmiştir. Ancak rölyef değişiminin antropojenik jeomorfoloji kapsamında temel boyutları ile dağılışını ve nedenlerini açıkladığı kuvvetle muhtemeldir. Bu bakımdan yapılan CBS temelli antropojenik jeomorfoloji çalışmasının sistematiksel olarak konu kapsamına farklı bir bakış açısı getireceği de düşünülmektedir. Ayrıca araştırmada jeomorfolojik koşulların antropojenik etkenlerle birçok parametre açısından değişime uğradığı sonucu farklı alanlara veri kaynağı sağlaması bakımından da önemlidir. İnceleme sahasında Kurbağalıdere'nin ıslah edilmesi, bu alanda rölyefin değişmesi, geçici derelerin ortadan kaldırılması, alt geçitlerin, ulaşım yollarının varlı̆̆ı, yüksek binaların inşaat koşulları, bina ve ulaşım nedenli istinat duvarları vb. unsurlar ilçedeki taşkın, su baskını, çökme, depremlerden etkilenme koşulları gibi hadiselerin hangi alanda daha yoğun oluşabileceği hakkında ön bilgi veriside oluşturabilmektedir. Çalışmada elde edilen bulgular, UA ve CBS tekonolojileriyle antopojenik jeomorfoloji çalışmalarında kullanılabilecek önemli veriler sağlamakta ve disiplinin gelişmesine, sistematiğine ve bakış açısına katkı sağlayabileceği düşünülmektedir. 


$\begin{array}{ccc}\text { Coğrafi Bilimler Dergisi } & \text { Cografi } \\ \text { Bilimler } \\ \text { Dergisi }\end{array}$

Analysis of Relief Change in the Scope of Anthropogenic Geomorphology: The Case of Ataşehir (İstanbul)

Murat Uzun*a

\section{EXTENDED ABSTRACT}

\section{Introduction}

The structure of the Earth, which is a long adventure, and the natural elements, characteristics and dynamic processes of the world have started to change rapidly and show different features with the participation of human beings in this adventure. Due to the resulting interactions and changes, the concept of anthropocene in the scientific community has been discussed in the natural environment and has been effective in its own place (Brandolini vd., 2019: 3; Crutzen ve Stoermer, 2000:17; Efe vd., 2008: 318; Ellis, 2017: 526; Steffen vd., 2011: 843; Syvitski 2012: 13; Jefferson 2013: 2; Zalasiewicz vd., 2008: 5; Zalasiewicz vd., 2015: 198). The fact that humanity, which enlarges its area of influence, has an impact on the geomorphological formation, development and operation processes and has become an important actor in this field has naturally led to the development of the concept of anthropogenic geomorphology. The recently emerged anthropogenic geomorphology, which has also been discussed within a wide range of systematic systems is defined as; human activities directly or indirectly interfere with morphogenetic processes, to reveal artificial shapes of different sizes or to cause changes in the existing topographic appearance (Brown et al., 2017: 75; Ertek 2015: 346; Ertek 2017: 73; Harden, 2013: 77; Karataş 2016: 444; Knitter vd., 2019: 3; Li vd., 2017: 113; Nir, 1983: 88; Özşahin, 2013b: 926; Rózsa 2007: 234; Rózsa ve Novak 2011: 110; Szabó and David, 2006: 18; Szabó et al., 2010: 6; Tarolli 2016: 2301; Ursu vd., 2011: 93; Uzun, 2020: 320; Verburg vd., 2016: 334; Walker, 1991: 3). In developing and expanding urban areas, topographic changes occur with focus on settlement, industry and transportation. This phenomenon, which has been intensified in our country since 1980s, has led to the emergence of cities with large population and urban sprawl areas. Turkey's most populated province is one of the first cities where the most significant events in İstanbul this situation. The changes in recent years have changed the topographic appearance within the boundaries of İstanbul-Ataşehir district and the relief has been reorganized. In this context, the aim of the study is to compare the old and new topographic data with different systematics via Geographical Information Systems (GIS) and to determine the distribution of the changing relief with different dimensions.

The study area consists of Ataşehir District boundaries of İstanbul province. In this respect, the study area is located on the Anatolian side of İstanbul and on the Kocaeli Plateau. Basically, physical

\footnotetext{
* Corresponding Author: Murat Uzun, murat_uzun53@ @otmail.com

a Marmara University, Institute of Social Sciences, Depearment of Geography, İstanbul/TURKEY https://orcid.org/0000-00032191-3936
} 
and human elements form the boundaries of the district. To the east of the district borders are Kayışdağ slopes and Camasirlik (Findıkl1) Creek, while the south is the D-100 highway, the north is the TEM (04) highway and the west is Libadiye Street. There are Ümraniye in the north, Sancaktepe in the northeast, Üsküdar in the west-northwest, Kadıköy in the southwest, and Maltepe in the south-southeast.

\section{Material and Method}

In the first phase of the research, the sources obtained as a result of the literature review on the subject and the field were examined, the conceptual framework was detailed and the geographical features of the study area were explained. Then, the provided base maps were transferred to ArcGIS 10.3 software and digitization and conversion operations were performed. First of all, the old and new Digital Elevation Model (DEM) data of the study area were created through topography sheets and AsterGDEM data. In order to determine the anthropogenic geomorphology conditions and relief changes in the study area, a multi-stage systematic was applied and all data were analyzed and compared in relation. The change in land use over the years was determined by controlled classification method from aerial photographs and Landsat satellite images, and the results were obtained and the preliminary information for the anthropogenic change areas of the study area and the relief changes were obtained. After these studies, the old (1980) and new (2016) DEM data were firstly analyzed in ArcGIS software with a raster calculator in three steps to determine the relief change. In the first stage, six different data were obtained by topographic analysis, in the second stage, three and third stage data were combined with thrust analysis and five different relief change analysis data were produced. Finally, as a result of old and new satellite imagery and field studies, relief change map was produced based on field observation data. In order to determine the anthropogenic factors of the relief change, the possible causes of impact were mapped. At the end of the study, relief change analyzes and anthropogenic effect factors were subjected to correlation analysis and the reasons of change were tried to be explained with numerically significant relationships.

\section{Findings}

In the study, according to the change analysis data of the elevation from the topographic analysis results in the first stage, relief change is observed in $18 \%$ of the field. The distribution dimension of the change is concentrated in the northern neighborhoods of the district via TEM highway and connection road. As a result of the slope analysis, it is understood that relief change occurs in $24 \%$ of the district area. The change is concentrated and observed in many areas of the district, especially the districts in the eastern and western parts of Kurbağalıdere. Relief changes were observed in $27 \%$ of the study area in the case of the analysis examined in the main aspects, whereas more than half of the study area experienced changes in all aspects of the analysis. This is likely to be the result of the geomorphological process of slope levelling, especially for transportation and settlement areas. The flow direction reveals that the relief has changed from past to present at a rate of 35\% in the study area. As a result of the topographic analysis, it is understood that different relief changes took place in the study area. It can be concluded that changes in elevation and slope are likely to developed under the common influence of erosion, deposition and flattening processes. In other analyses, it becomes clear that straightening 
process may be in the foreground more, which will naturally lead to micro-scale relief changes on topography.

In the study, the situation of the lowest places in terms of relief change is that $33 \%$ of the district area is experiencing change. When the distribution of the data is examined, especially the TEM connection road, the change in the northern part of Barbaros and Atatürk neighborhoods, it reveals that there is either erosion or accumulation activity in these areas. Analysis of the highest areas reveals that relief change occurs in a very large area. Except for the southern parts of İIçerenköy, Yenisahra, Örnek, Fetih and Barbaros districts, it is seen that $77 \%$ of the district area has experienced relief changes. In the analysis of altitude differences, $68 \%$ of the district shows that the change of relief occurs.

As a result of the Elevation-Slope (RE) thrust analysis, a change was detected in 39\% of the district area. Areas where change is concentrated are mostly observed around the TEM highway. In other overlay analyses, the rate of change has always been observed in more than half of the district area. Since this is affected by many factors due to the micro and macro scale of the relief change, the change of anthropogeomophological conditions naturally affects the entire dynamic morphological structure. In addition, even leveling-leveling operations for transportation, erosion activity created for the settlement area or even micro-scale deposition for area correction reveal the presence of change in the field.

All analysis data in the study area were evaluated and anatropogeomorphological relief change map based on observation and measurement data was created as a result of field studies. Relief change analysis applied to this map, as well as other analyses, has shown relief changes in $29 \%$ of Ataşehir district. When the distribution of change is observed, it is seen that it mostly concentrated in Barbaros, Atatürk, Ferhatpaşa, Küçükbakkalköy and Yenişehir neighborhoods.

When the correlation analysis results were evaluated in general, all factors caused changes in relief and artificial surface shapes appeared in some areas. D-100 highway, TEM motorway and connection roads are the main factors that cause the most change in the elevation due to transportation. In addition, the multi-storey buildings and new residential areas built in the north of the Barbaros Quarter and the Atatürk Quarter show that the defective surface was reshaped by erosion and flattening. Slope values are concentrated in certain areas due to the flattening activity for settlement and transportation areas. It is understood that change of view (main directions) changes in parallel with the transportation network, but it is affected by all anthropogenic factors based on all directions. In the altitude difference analysis, it is seen that the change analysis of the lowest places are concentrated in areas where there is a high number of building floors, urban development is close to the present day, as well as where there are more main road routes and wider roads. High areas and altitude difference analyses are affected by all anthropogenic factors, revealing that levelling-flattening is taking place in most areas except the oldest settlements of the district area. All the findings indicate that the human activities mentioned in the study area have created changes in relief on micro and macro scale, in large and narrow areas. In this case, the topographic view was reorganized and anthropogeomorphological conditions occurred due to the fact that the entire site was a settlement area and the change to be created by human activities. 


\section{Conclusion}

Relief change analysis with the effective use of Geographical Information Systems (GIS) in the case of Ataşehir has led to the detection of many changes in relief due to different anthropogenic factors. Relief change analyses performed in the study were applied in three different stages and many change analysis data were presented. In particular, the relationship between altitude and slope analyses with settlement and transportation areas, anthropogenic factors, revealed the anthropogenic geomorphology structure of the district and clarified the main reasons for relief change. Basic anthropogenic factors such as land use status, urban development, density of building floors and transportation structure of Ataşehir caused micro and macro scale changes in almost every point of the district. In particular, the D-100 highway, the TEM motorway and the connecting road have affected many morphogenetic processes in terms of elevation and slope, resulting in large dimensional changes in the terrain. In the last 15 years, the engineering works of the high-rise buildings have led to the arrangement of the land and have changed with the relief-digging process. The fact that only $30 \%$ of the relief changes can be observed in the field observations shows that the natural structure of the land has completely changed and anthropogenesis has assumed the main role in the morphogenetic process.

\section{Referanslar/References}

Ak, A. (2010). Kayışdağı ve Çevresinin Jeomorfolojisi. İstanbul Üniversitesi Sosyal Bilimler Enstitüsü Coğrafya Anabilim Dalı, Yayınlanmamış Yüksek Lisans Tezi, İstanbul. https://tez.yok.gov.tr/UlusalTezMerkezi/262835 adresinden edinilmiştir.

Brandolini, P., Cappadonia, C., Luberti, G., Donadio, C., Stamatopoulos, L., Di Maggio, C., Faccini F., Stanislao, C., Vergari, F., Paliaga, G., Agnesi, V., Alevizos, G., Del Monte, M. (2019). Geomorphology of the Anthropocene in Mediterranean Urban Areas. SAGE Progress in Physical Geography, 20 (10), 1-34. doi: 10.1177/0309133319881108.

Brown, E. H., (1970). Man Shapes The Earth. Geographical Journal, The Royal Geographical Society (with the Institute of British Geographers), 136, 74-85. doi: 10.2307/1795683.

Brown, A. G., Tooth, S., Bullard, J. E., Thomas, D., Chiverrel, R., Plater, A., Murton, J. (2017). The Geomorphology of the Anthropocene: Emergence, status and implications. Earth Surface Processes and Landforms, 42, 71-90. doi: 10.1002/esp.3943.

Castree, N. (2014). The Anthropocene and Geography I: The Back Story. Geography Compass, 8, 436-449. doi: $10.1111 /$ gec 3.12141.

Crutzen, P. J., Stoermer E. F. (2000). The Anthropocene. Global Change Newsletter, 41, $17-18$. http://www.igbp.net/download/18.316f18321323470177580001401/1376383088452/NL41.pdf adresinden alınd1.

Döker, M. F., (2012). İstanbul Kentsel Büyüme Sürecinin Belirlenmesi, İzlenmesi ve Modellenmesi, İstanbul Üniversitesi Sosyal Bilimler Enstitüsü Coğrafya Anabilim Dalı, Yayınlanmamış Doktora Tezi, İstanbul. https://tez.yok.gov.tr/UlusalTezMerkezi/317749 adresinden edinilmiştir.

Efe, R., Soykan, A., Cürebal, İ., Sönmez, S. (2008). Türkiye’de Antroposen Döneminde Doğal Çevre Bozulmasını Etkileyen Antropojenik Faktörler, TÜCAUM V. Ulusal Coğrafya Sempozyumu Bildiriler Kitabı, (317-328), 16-17 Ekim 2008. Ankara.

Ekinci, D. (2006). Tuzla Kıyıları ve Yakın Çevresinde İnsan Kontrollü Güncel Jeomorfolojik Gelişim. Türk Coğrafya Dergisi, 46, 123-145. http://dergipark.org.tr/tr/pub/tcd/issue/21235/227866 adresinden alınd.

Ekinci, D., Yalçınkaya, B. (2015). İstanbul'da Antropojenik Süreçler ve Etkileri. IV. Ulusal Jeomorfoloji Sempozyumu Bildiriler Kitabl, (347-368) Samsun.

Erkal, A. (2018). Körfez İlçesi’nde (Kocaeli) Antrpojeomorfolojik Araştırmalar. Bilecik Şeyh Edebali Üniversitesi, Sosyal Bilimler Enstitüsü, Coğrafya Anabilim Dalı Yayınlanmamış Yüksek Lisans Tezi, Bilecik. https://tez.yok.gov.tr/UlusalTezMerkezi/51415 adresinden edinilmiştir. 
Erkal, T., Taş, B. (2013). Jeomorfoloji ve İnsan, (Uygulamalı Jeomorfoloji). İstanbul: Yeditepe Yayınevi.

Ellis, E. C. (2017). Physical Geography in the Anthropocene. Progress in Physical Geography SAGE, 41 (5), 525-532. doi: $10.1177 / 0309133317736424$.

Ertek, T. A. (2008). Morfodinamik Süreçlere Dayanarak İstanbul İli'nin Jeomorfolojisi. Ulusal Jeomorfoloji Sempozyumu (2023 Ekim 2008) Bildiriler Kitabı (267-268) Çanakkale.

Ertek, T. A. (2010). İstanbul'un Jeomorfolojisi. TMMOB Jeoloji Mühendisleri İstanbul'un Jeolojisi Sempozyumu Bildiriler Kitabı (Editörler: Örgün, Y., Şahin, S. Y.), (21-48) İstanbul.

Ertek, T. A. (2015). Antropojenik Jeomorfolojinin Ana Çizgileri. IV. Ulusal Jeomorfoloji Sempozyumu Bildiriler Kitabı, (346) Samsun.

Ertek, T., A. (2016). İnsan Faaliyetlerine Bağlı Jeomorfokronolojik Yıkımlar. TÜCAUM Uluslararası Coğrafya Sempozyumu Bildiriler Kitabı, (201-219) Ankara.

Ertek, T. A. (2017). Antropojenik Jeomorfoloji: Konusu, Kökeni ve Amac1. Türk Coğrafya Dergisi, 69, 69-79. doi: $10.17211 /$ tcd.319409.

Golomb, B., Eder, H. M. (1964). Landforms Made by Man. Landscape, 13, 4-7.

Goudie, S. A. (1993). Human Influence in Geomorphology. Geomorphology, 7, 37-59. doi: 10.1016/0169-555X(93)90011-P.

Goudie, A, Viles, H. (2016). Geomorphology in the Anthropocene. United Kingdom: Cambridge University Publishers.

Güner, Ö. (2019). Atakum'daki (Samsun) Antropojeomorfolojik Yapılar ve Çevresel Etkileri. Doğu Coğrafya Dergisi, 24 (42), 1-15. doi: 10.17295/ataunided.620592.

Harden C. P. (2013). The Human-Landscape System: Challenges for geomorphologists. Physical Geography, 35 (1), $76-89$. doi: 10.1080/02723646.2013.864916.

Harden, C. P., Chin, A., English, M. R. (2014). Understanding Human-Landscape Interactions in the Anthropocene. Environmental Management, 53, 4-13. doi: 10.1007/s00267-013-0082-0.

Jefferson A. J., Wegmann K. W., Chin A. (2013). Geomorphology of the Anthropocene: Understanding The Surficial Legacy of Past and Present Human Activities. Anthropocene, 1 (2), 1-3. http://all-geo.org/jefferson/wpcontent/uploads/2015/05/13_Jefferson_et_al_preface_Anthropocene_2013.pdf adresinden alınd1.

Karataş, A. (2016). Üsküdar'da Rölyefin Yeniden Tanzimi: Antropojenik Jeomorfoloji ve Yansımaları. Uluslararası Üsküdar Sempozyumu Bildiriler Kitabı Cilt II, (443-453) İstanbul.

Knitter, D., Augustin, K., Biniyaz, E., Hamer, W., Kuhwald, M., Schwanebeck, M., Duttmann, R. (2019). Geography and the Anthropocene: Critical Approaches Needed. SAGE Progress in Physical Geography, 20 (10), 1-11. doi:10.1177/0309133319829395.

Kopar, İ., Çelik M., Bayram, H. (2018). Kapadokya Volkanik Provensi'ndeki Volkan Rölyefinin Antropojenik Degradasyonu Üzerine Bir Analiz. Türk Coğrafya Dergisi, 71, 37-46. doi: 10.17211/tcd.424377.

Li, J., Yang, L., Pu, R., Liu, Y. (2017). A Review on Anthropogenic Geomorphology. Journal of Geographical Sciences, 27 (1), 109-128. doi: 10.1007/s11442-017-1367-7.

Manea, Ş., Surdeanu, V., Rus, I. (2011). Anthropogenic Changes on Landforms in the Upper And Middle Sectors of Strei Basin, Rev. Roum. Géogr./Rom. Journ. Geography, $55 \quad$ (1), 37-44. http://www.rjgeo.ro/atasuri/revue\%20roumaine_55_1/S.\%20Manea\%20et\%20al.pdf adresinden alınd1.

Nir, D. (1983). Man, A Geomorphological Agent. An Introduction to Anthropic Geomorphology. Dordrecht, Boston, London: Reidel.

Özşahin, E., Ekinci, D. (2013). İstanbul'un Anadolu Yakasının Jeomorfolojik Özelliklerinin Ana Çizgileri, İstanbul Üniv. Edebiyat Fakültesi Coğrafya Bölümü, Coğrafya Dergisi, $27, \quad$ 14-37. http://dergipark.org.tr/tr/pub/iucografya/issue/25072/264634 adresinden alınd1.

Özşahin, E. (2013a). İstanbul İlinin Anadolu Yakasının Jeomorfolojik Özellikleri. İstanbul Üniversitesi Sosyal Bilimler Enstitüsü Coğrafya Anabilim Dalı, Yayınlanmamıș Doktora Tezi, İstanbul. https://tez.yok.gov.tr/UlusalTezMerkezi/340380 adresinden edinilmiştir.

Özşahin, E. (2013b). Asi Nehri Deltasının (Hatay) Antropojenik Jeomorfolojisi. Ertuğ Öner (Ed.) Profesör Doktor Illhan Kayan'a Armăgan içinde (925-934). İzmir: Ege Üniversitesi Yayınları.

Rózsa, P. (2007). Attempts at Qualitative and Quantitative Assessment of Human Impact on the Landscape. Geogr Fiz Dinam Quat, 30, 233-238. 
Rózsa, P. (2010). Nature and Extent of Human Geomorphological Impact - A Review, Anthropogenic Geomorphology, A Guide to Man-Made Landforms, Edt Sbazo vd., (273-293). Dordrecht Heidelberg London New York: Springer.

Rózsa P., Novák T. (2011). Mapping Anthropogenic Geomorphological Sensitivity on Global Scale Zeitschrift für Geomorphologie 55 (1), 109-117. doi: 10.1127/0372-8854/2011/0055S1-0041

Steffen, W. Grinevald, J. Crutzen, P. (2011). The Anthropocene: Conceptual and Historical Perspectives. Philosophical Transactions of the Royal Society, 369, 842-867. doi: 10.1098/rsta.2010.0327.

Syvitski, J. (2012). Anthropocene: An Epoch of Our Making. Global Change, 78, 12-15. http://www.igbp.net/news/features/features/anthropoceneanepochofourmaking.5.1081640c135c7c04eb480001082.ht $\mathrm{ml}$ adresinden alınd1.

Szabó, J., David, L., Loczy, D. (2010). Anthropogenic Geomorphology, A Guide to Man-Made Landforms, Dordrecht Heidelberg London New York: Springer.

Szabó, J. (2010). Anthropogenic Geomorphology: Subject and System. J.Szabó, L.Dávid, D.Lóczy (Ed.) In Anthropogenic Geomorphology (A Guide to Man -made Land forms) (3-10). Dordrecht Heidelberg London New York: Springer.

Şengör, A. M. C., Özgül, N. (2010). İstanbul'un Jeolojisi, İstanbul Ansiklopedisi. İstanbul: NTV Yayınları.

Tarolli, P (2016). Humans and the Earth's Surface. Earth Surface Processes and Landforms, 41, 2301-2304. doi: 10.1002/esp.4059.

Tarolli, P., Sofia, G. (2016). Human Topographic Signatures and Derived Geomorphic Processes Across Landscapes, Geomorphology, 255, 140-161. doi: 10.1016/j.geomorph.2015.12.007.

Ursu A, Chelaru D. A, Mihai F. C., Iordache, İ. (2011). Anthropogenic Landform Modeling Using GIS Techniques Case Study: Vrancea Region. Geographia Technica, 13 (1), 91-100. doi: 10.5281/zenodo.19144.

Uzun, M. (2020). Anthropogenic Geomorphology in The Dilderesi Basin (Gebze-Dilovas1): Changes, Dimensions and Effects. International Journal of Geography and Geography Education (IGGE), 41, 319-345. doi: 10.32003/igge.623378.

Verburg, P. H., Dearing, J. A., Dyke, J. G. (2016). Methods and Approaches to Modelling the Anthropocene. Global Environmental Change, 39, 328-340. doi: 10.1016/j.gloenvcha.2015.08.007.

Walker, H. J. (1991). Antropojenic Landforms in the Coastal Zone (Sahil bantlarında Antropojenik Yerşekilleri). Jeomorfoloji Dergisi Özel Sayl, 19, 1-12.

Xiang, J., Li, S., Xiao, K., Chen, J., Sofia, G., Tarolli, P. (2019). Quantitative Analysis of Anthropogenic Morphologies Based on Multi-Temporal High-Resolution Topography. Remote Sensing, MPDI, 11 (1493), 1-20. doi:10.3390/rs11121493.

Zalasiewicz, J., Williams, M., Smith, A., Barry, T. L., Coe, A. L., Bown, P. R., ... , Gregory, F. J. (2008). Are we now living in the Anthropocene?. GSA Today, 18, 4-8. doi: 10.1130/GSAT01802A.1.

Zalasiewicz, J., Waters, C. N., Williams, M., Barnosky, A. D., Cearreta, A., Crutzen, P., ... , Haff, P. K. (2015). When did the Anthropocene begin? A mid-twentieth century boundary level is stratigraphically optimal. Quaternary International, 383, 196-203. doi: 10.1016/j.quaint.2014.11.045. 